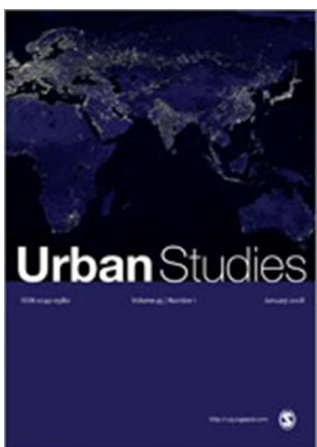

\title{
Evaluation of the Local Employment Impacts of Enterprise Zones: A Critique
}

\begin{tabular}{|r|l|}
\hline Journal: & Urban Studies \\
\hline Manuscript ID & CUS-1115-17-12.R1 \\
\hline Manuscript Type: & Article \\
\hline $\begin{array}{r}\text { <b>Discipline: Please select a } \\
\text { keyword from the following list } \\
\text { that best describes the } \\
\text { discipline used in your paper.: }\end{array}$ & Economics \\
\hline $\begin{array}{r}\text { World Region: Please select } \\
\text { the region(s) that best reflect } \\
\text { the focus of your paper. } \\
\text { Names of individual countries, } \\
\text { cities \& economic groupings } \\
\text { should appear in the title } \\
\text { where appropriate.: }\end{array}$ & Western Europe, North America \\
\hline $\begin{array}{r}\text { Major Topic: Please identify up } \\
\text { to } 5 \text { topics that best identify } \\
\text { the subject of your article.: }\end{array}$ & Employment/Labour, Policy, Redevelopment/Regeneration \\
\hline $\begin{array}{r}\text { You may add up to } 2 \text { further } \\
\text { relevant keywords of your } \\
\text { choosing below:: }\end{array}$ & Evaluation, Local development \\
\hline
\end{tabular}

\section{SCHOLARONE \\ Manuscripts}




\title{
Evaluation of the local employment impacts of enterprise zones: A critique
}

\begin{abstract}
Enterprise zone policy is a potential tool for the regeneration of distressed areas, based primarily on tax incentives to businesses locating in the target areas. The tool has been tested in several countries over more than 35 years but there is no consensus on whether or not it is effective and efficient in creating jobs and reducing unemployment in targeted localities. This paper reviews seminal enterprise zone evaluations in the United Kingdom, United States and France. More than one-half of the studies reported local employment benefits but the others reported none and information is limited on what affects policy success. The paper argues that typically narrow-focus research designs and a-theoretical evaluation have contributed to the lack of consensus and policy insight, potentially exacerbated by non-exact data. It proposes richer evaluations with explicit theoretical frameworks, such as the one presented in the paper, more comparative work and use of more accurate data.
\end{abstract}

\section{Keywords}

Enterprise Zones, Evaluation, Employment, Tax Incentives, Local Development 


\section{Introduction}

Enterprise zone policy aims to stimulate economic development in localities where market forces have not been able to bring about regeneration. Its central feature is the award of tax incentives to businesses within designated zone locations, typically for capital investment or employment. Simplified regulation may also be included, notably on land use planning. The policy has operated in various forms and countries for more than 35 years. Recently, OECD (2016) identified 16 OECD countries operating special economic zone policies, including enterprise zone policies in the United Kingdom, the United States, France, Korea and Poland.

This paper reviews seminal evaluations of the local employment impacts of enterprise zones in the UK, the USA and France. Despite a significant evaluation literature, no consensus has emerged on whether or not enterprise zones are effective or efficient in delivering local employment benefits. On the one hand, some researchers have made negative summaries, such as: "enterprise zones have not been successful" (Peters and Fisher, 2002); "at least at the historical level of expenditures, enterprise zones are not an effective way of increasing the probability that the residents of distressed areas are employed" (Elvery, 2009); and "while enterprise zones have been studied extensively, there is little evidence that they have succeeded" (Greenbaum and Landers, 2009). On the other hand, more than one-half of the seminal papers reviewed here have identified positive local employment impacts from enterprise zone programmes, and several suggest that reasonable value for public money has been obtained (O'Keefe, 2004; Rubin, 1990; Rubin and Wilder, 1989; PACEC, 1987, 1995; Busso, Gregory and Kline, 2013; Freedman, 2012; Papke, 1993; Erickson and Friedman, 1990a, 1990b, 1991). This paper considers what might be behind the discrepancies in findings on the local employment impacts of enterprise zones and how future research might deliver greater consensus and policy insight.

The paper starts by describing the objectives and origins of enterprise zone policy and its operation in the UK, USA and France. It then offers a theoretical framework to illustrate a range of processes through which enterprise zones may influence local employment, suggesting issues that should be considered by evaluation. Evaluation findings are then reviewed on employment impacts and the factors influencing them, including consideration of evidence gaps. Some data weaknesses are then highlighted. The paper concludes with a call for more theoretically-based evaluations, more comparisons across zone designs and contexts, and the use of richer and more precise data. 


\section{Objectives, origins and operation of enterprise zone policy}

\section{Objectives}

Governments tend to view enterprise zone policy as a means of stimulating growth in places in which market forces have been unable to secure recovery from shock, recognising a potential to improve national efficiency and equity as well as local outcomes. Its appropriateness to the challenge largely depends on how far it can remedy the market and institutional failures underlying the local problems. The spatial mismatch hypothesis suggests that unemployed inner-city job seekers may lack access to non-local job vacancies - for example because of missing information, networks, or transport (Gobillon, Selod and Zenou, 2007; Ihlanfeldt and Sjoquist, 1998). Renewed labour demand may be impeded by barriers to business investment, such as negative externalities from past decline (e.g. loss of skills and work readiness, out-migration of skilled workers); a poor match between the competences of displaced workers and new jobs; downwardly sticky wages; or high local business tax rates. Property markets may leave local sites and premises redundant as a result of negative externalities from dereliction; lack of information on property values following redevelopment; indivisibilities and scale economies in development; and costly, slow and uncertain planning procedures (PACEC, 1995).

Enterprise zones seek to respond by using investment and employment subsidies for businesses located in zones together with property development subsidies and regulatory changes. They may be able to address labour market failures by creating jobs in locations where they can be accessed by job seekers; increasing wages to market clearing levels; removing negative externalities affecting worker competences and business perceptions of investment opportunities; and reducing local business taxes. They might address property market failures by raising the rate of return to property investment and reducing planning constraints. The policy can be seen largely as a demand-side, place-based approach. It can be contrasted with people-based policies (focused on increasing employment opportunities wherever people live) and supply-side place-based policies (e.g. training and job matching for displaced workers).

\section{Origins and operation}


The origins of enterprise zone policy lie in a 1977 address by Sir Peter Hall to the British Royal Town Planning Institute in which he suggested an enterprise zone experiment as a possible 'last ditch' solution to Britain's inner-city crisis. It would pare back business taxation and regulations to a minimum in a few inner-city locations with severe unemployment and derelict land so as to attract business relocations and stimulate small firm development (Hall, 1982, 417). The relocations would take activity from other places, but they could deliver a net benefit by drawing unemployed inner-city residents into the labour market as displaced workers in more prosperous areas found alternative jobs. The zones might also generate new activity by stimulating small business creation and growth, and gradually progress inner-city residents up a skills and incomes ladder.

The idea was taken up by the UK's Thatcher government, which established 23 enterprise zones between 1981 and 1984. The zones offered business taxation incentives and simplified planning regulations for 10 years in a mix of inner city, suburban and rural areas with high unemployment and vacant sites. Further designations followed from the mid-1980s to 1996. The UK reintroduced enterprise zones in a modified form in 2012, designating 35 zones initially. The Mark II zones offer a lower value and duration of incentives, restrict benefits to small firms and new-to-zone activities (excluding local relocations), and target areas with capacity for growth in priority sectors as well as regeneration need.

\section{[Insert Table 1 here]}

US state governments started to create enterprise zones from the early 1980 s and most states have operated zones since then, typically using mixtures of employment and investment incentives. In 2017, 21 states operated zones. US federal government has also been active, operating 40 Empowerment Zones, 20 Enterprise Communities and 40 Renewal Communities in the 1990s and early 2000s, and creating 22 Promise Zones in 2014.

The French government also operates enterprise zones. This was initially in the form of 100 Zones Franches Urbaines, which ran from 1997 to 2014 in urban areas with very high unemployment offering reduced corporate taxes, property taxes and social security contributions. The programme was extended until 2020 in the less generous form of Territoires Entrepreneurs. 
Further details of the programmes are given in Table 1.

\title{
3. A theoretical framework for enterprise zone evaluation
}

\begin{abstract}
Although some enterprise zone evaluations have followed comprehensive theoretical frameworks (Busso, Gregory and Kline, 2013; PACEC, 1987, 1995), most of the employment-focused evaluations have concentrated on the relationship between zone status and headline employment outcomes. Richer evaluations will require more detailed theoretical frameworks. Figure 1 offers a framework exploring neoclassical firm and place equilibrium effects and the influence of factor mobility, substitution and price elasticity, although other theoretical views could be taken. The processes in this framework may be influenced by differences in zone programme designs and contexts, and hence potentially help explain differences across the literature in evaluation findings.
\end{abstract}

[Insert Figure 1 here]

The top of the Figure illustrates channels through which enterprise zone incentives could increase employment and property demand. It classes the incentives into employment, capital equipment and real estate subsidies. A key channel involves reduced unit output costs for firms from employment and capital subsidies, and from real estate subsidies if the firm owns its own premises. The increased profitability may lead to net firm in-migration and enable pre-existing establishments to reduce prices or increase investment (in products, equipment, training, marketing etc.), hence increasing their competitiveness and stimulating expansion. This may increase demand for labour and property.

The framework suggests some potential mediating influences. If capital subsidies are large compared to employment subsidies then labour demand growth could be counterbalanced by capital-labour substitution, which could be a particular problem in manufacturing-dominated zones, since substitution may be easier in manufacturing. Incumbent establishments could also respond to increased profitability by distributing profits rather than reducing prices or investing, although limiting subsidies to new recruitment or new-to-zone firms might address 
the issue. Third, reduced business operating costs could be capitalised by property owners in increased rents and prices, particularly if supply is constrained.

The bottom of the Figure illustrates how increased labour and property demand, and increased returns on property investment brought about by real estate subsidies, may stimulate growth by increasing the effective supply of labour and land. The emphasis is on reductions in long-term unemployment, which is seen as net of macroeconomic crowding out and hence as a national gain rather than a spatial redistribution. Self-reinforcing local agglomeration benefits could also be generated. The framework also suggests a possible impact on equity as employment and income outcomes improve for poorer localities and people.

The framework also suggests some further potential explanations for the discrepancies that have emerged in enterprise zone evaluation findings. For example, new employment could go to inactive labour, commuters or in-migrants rather than the unemployed, and the extent to which this happens may be affected by local context (e.g. large urban areas may see more inward commuting). Wage growth might also reduce employment growth, particularly in places and periods of constrained labour supply. A displacement of long-term unemployment to neighbouring areas could also occur, which would be damaging if those areas also have high long-term unemployment. The importance of these effects may vary with local context and with programme design, potentially helping explain variations in evaluation results across different programmes.

\title{
4. Key evaluation findings
}

\section{Do enterprise zones increase local employment or reduce unemployment?}

\author{
[Insert Table 2 here]
}

Table 2 provides summary information on the local employment findings of enterprise zone evaluations. It clearly reveals the discrepancies. Of 34 evaluations, 21 found that enterprise zone intervention increased employment or reduced unemployment, whereas 12 found that 


\section{Unemployment impacts}

The majority of the studies that investigated impacts on local unemployment found benefits, although the precise measures varied. Ham et al. (2011) found that federal empowerment zones reduced the zone unemployment rate by an average of 9 percentage points and that a

range of state enterprise zone programmes reduced the zone unemployment rate by an

\section{Employment impacts}

Several evaluations of US state and federal interventions found no impact on local employment levels, one found a negative employment impact (Lambert and Coomes, 2001), and one found mixed results (Lynch and Zax, 2011). In contrast, several evaluations found substantial employment benefits. PACEC (1995) found that UK Mark 1 enterprise zones generated a near three-fold increase in local employment levels over 10 years. Two US federal empowerment zone evaluations put the policy-generated increase in local employment at 34\% (Ham et al, 2011) and 15\% (Busso, Gregory and Kline, 2013). Among US state programme evaluations, policy was found to have increased local employment by more than one-third in Indiana (Rubin and Wilder, 1989), by an average of $10 \%$ across 17 states (Erickson and Friedman, 1990a, 1990b, 1991) and by 10\% in Texas (Freedman, 2012). In France, Rathelot and Sillard (2008) found that zones had stimulated a local employment increase of approximately 15\%, and Mayer, Mayneris and Py (2017) found a local employment increase of $24 \%$. In between those evaluations showing substantial employment impacts and those estimating no benefits, there are several studies that found benefits that were relatively modest in scale. One US federal empowerment zone evaluation found an increase of only 130 jobs (Hanson and Rohlin, 2011, 2013), another found a modal increase across census tracts of approximately 13 jobs (Rich and Stoker, 2010), an evaluation of the Colorado state programme found an employment increase of $4 \%$ (Billings, 2009) and an evaluation of the California state programme found an employment increase in the order of 5\%. In France, Givord, Rathelot and Sillard (2013) found increases of between 3 and 12 percentage points in employment and hours worked on zones. 
average of 1.6 percentage points. Sridhar (2000) found that one state programme had reduced local unemployment by 2.9 percentage points. On other measures, Papke (1994) found that a US state programme had reduced numbers of local unemployed people by $19 \%$, Gobillon et al (2010) found that French zones increased the exit rate from unemployment into a job by $3 \%$ per semester for local residents, and Rich and Stoker (2010) found that US federal empowerment zones reduced unemployment in one-half of the cities they evaluated. On the other hand, Oakley and Tsao (2006) found that US empowerment zones had no impact on local unemployment while Rogers and Tao (2004) detected no statistically significant impact of Florida small city zones on the unemployed-to-population ratio.

\section{Are enterprise zones cost effective?}

Although many evaluations found employment benefits, only 10 compared the benefits with costs so as to permit some assessment of whether the policy could be considered cost effective. The majority of these found public costs per job created that might be considered to be very broadly in line with results achieved by similar interventions such as UK regional policy or US job subsidies. Five found cost-per-job created below approximately 8000 USD per annum in 2016 prices (O’Keefe, 2004; Rubin, 1990; Rubin and Wilder, 1989; PACEC, 1987, 1995). Three found cost-per-job created of between approximately 8000 USD and 20 000 USD per annum in 2016 prices (Busso, Gregory and Kline, 2013; Freedman, 2012; Papke, 1993). Erickson and Friedman (1990a, 1990b; 1991) and Rubin (1990) both concluded that enterprise zone policy had a negative cost per job once additional tax revenues generated had been taken into account. On the other hand, Rathelot and Sillard (2008) and Hanson and Rohlin (2011) estimated very high costs per job created, while of course several evaluations found no employment benefits that could be weighed against costs incurred.

\section{What factors influence the employment impacts of enterprise zones?}

Although in a few cases evaluations have produced different findings for essentially the same zone programmes in the same places and at the same times, the various evaluation studies are generally associated with different programmes and different contexts. Indeed there has been a richness of policy experimentation that might offer important insights in how to strengthen enterprise zone policy design by clarifying how different policy designs and contexts interact 
with processes affecting local employment outcomes, such as those suggested in Figure 1. Regrettably, few evaluations have systematically investigated these potential influences, but several evaluations offer useful indications that certain processes highlighted in the Figure merit more evaluation attention.

\section{Capital-labour substitution}

The extent to which zone employment generation is impeded by capital-labour substitution in existing zone firms and high capital intensity in new-to-zone firms could vary with factors such as the relative value of capital and labour subsidies in zone packages, whether or not subsidies are conditioned on recruitment or capital investment and the relative importance within zones of industries with high capital-labour substitutability. Certain studies offer insights. Papke $(1993,1994)$ found that a capital-weighted subsidy resulted in increased employment as well as capital use. Greenbaum and Engberg (2004) and Bondonio and Greenbaum (2007) found that increased capital use by incumbent firms did not explain the absence of employment generation across the range of zone programmes they studied. On the other hand, Lynch and Zax (2011) argued that greater capital-labour substitution among establishments on urban zones might explain why rural zones had generated employment increase while urban zones did not, and could have been related to lower rural wage rates.

\section{Labour and wage elasticity}

If labour supply is constrained, increased employment demand generated by zone intervention might have much stronger impacts on wage rate growth than employment growth. The evidence from the evaluations is not very clear on how far this is an issue. There are few studies showing that an increase in wage rates has reduced employment growth, perhaps reflecting a genuine targeting of zones on areas with labour surplus. For example, O'Keefe (2004), Givord, Rathelot and Sillard (2013) and Mayer, Mayneris and Py (2017) all found that the zone employment growth that occurred was in situations where zone wage rates remained stable overall. Indeed, the latter authors found that the wage rates of non-lowwage workers fell, reflecting reduced relative demand for these workers. Other studies found that zone wage rates and employment volumes moved hand-in-hand (Busso, Gregory and Kline, 2013; Ham et al, 2011) or did not move at all (Oakley and Tsao, 2006). Greenbaum 
and Engberg (2004) and Bondonio and Greenbaum (2007) found that zones reduced average wages (possibly due to requirements in some states that new hires are zone residents) but still did not increase employment.

\section{Capitalisation of subsidies}

One of the processes that might explain why enterprise zones sometimes do not create employment is a potential capitalisation of enterprise zone subsidies by property investors, developers and landowners. They may be able to react to the increased property demand by increasing the sale or rental prices of land and premises on zones, until the profitability of firms is equal on and off zones, leaving firms indifferent to an on-zone or off-zone location (Bond, Gardiner and Tyler, 2013; Landers, 2006). The scale of capitalisation could be influenced by factors such as the scale of availability of vacant local premises and the share of tenants and owner-occupiers on zones. The evaluations provide some evidence of capitalisation. PACEC (1995) found an accrual of subsidy values to landlords through rental appreciation of between $20 \%$ and $50 \%$ on the majority of UK Mark 1 zones. The rate was highest in tight property markets and fell towards the end of the zone lifetimes. Similarly, Hanson (2009) found that US Empowerment Zones had a substantial positive impact on median property values, which increased by over USD 100 000. On the other hand, Boarnet and Bogart (1996) found that New Jersey enterprise zones did not affect property values.

\section{Distribution of job gains}

The share of new zone jobs going to in-commuters, new residents and people who were formerly inactive in the labour market rather than long-term unemployed residents could vary with factors such as the size of zones relative to their travel-to-work areas and whether or not the incentives are tied to hiring long-term unemployed residents. Some evaluations found that quite high proportions of jobs went to zone residents and the unemployed. On Mark 1 UK zones, approximately $90 \%$ of non-managerial/professional recruits were local residents and approximately $34 \%$ of recruits were previously unemployed (PACEC, 1995). Erickson and Friedman (1990a, 1990b, 1991) estimated that approximately $61 \%$ of jobs went to residents and approximately $48 \%$ to the unemployed on US state zones. On Texas zones, workplace employment growth only slightly exceeded resident employment growth (Freedman, 2012). 


\section{Displacement of activity from outside of zones}

Relocation or displacement of economic activity onto zones that would otherwise go elsewhere could be expected to offset the job creation benefits of zone policies, at least in so far as the activity is displaced from other high unemployment areas. The degree of displacement could be affected by factors such as the distance of zones from other distressed areas and whether or not zone incentives are available for relocations. There is evidence from some of the evaluations that displacement can be a significant problem. By mid-lifetime on the UK Mark 1 zones, approximately $25 \%$ of new jobs had been displaced from other highunemployment areas through establishment relocations; a further $31 \%$ of jobs were in inward investors that had chosen enterprise zones over alternative locations (which could include other high unemployment areas) (PACEC, 1987). At the end of the UK Mark 1 zone lifetimes, the net job loss to the areas surrounding the zones was estimated at $51 \%$ of the jobs created within the zones (PACEC, 1995). Hanson and Rohlin (2011, 2013) found even larger displacement onto US urban empowerment zones from neighbouring and similar areas, which nearly completely offset the employment benefits generated within the zones. In France, Mayer, Mayneris and Py (2017) found that all zone employment growth was the result of relocations or diversion of new establishment creations from the rest of the municipality hosting a zone; i.e. the policy generated no additional activity for municipalities hosting zones overall. Similarly, Givord, Rathelot and Sillard (2013) found negative spillovers from French zones on establishment stocks in the 300-metre rings surrounding zones, which nearly fully counterbalanced the growth in the on-zone establishment stock. On the other hand, Rathelot and Sillard (2008) and Gobillon, Magnac and Selod (2010) did not find important displacement effects on neighbouring municipalities from French urban zones. Furthermore, various US state enterprise zone policy evaluations found no displacement from other local areas (Greenbaum and Engberg, 2004; Neumark and Kolko, 2010; Freedman, 2012), while Ham et al (2011) found that the limited local spillovers that did exist were positive.

\section{Sites and premises availability}


The ability of certain enterprise zones to offer large volumes of available sites and premises to accommodate new business activity could have an important influence on the scale of employment impacts. Much of the success of the UK Mark 1 zones was attributed to an increase of $60 \%$ in the floor space available on the zones between their designation and the mid-point of their lifetimes. This was the result of the presence of large empty and redundant sites within designated zone areas combined with public investments in removal of dereliction and landscaping, streamlining of planning procedures, incentives for property investors, and subsidies to premises occupants (PACEC, 1987). Enterprise zone job creation effects could be more limited in places where land and premises are more constrained.

\title{
What is the influence of different zone programme designs and zone contexts?
}

\author{
[Insert Table 3 here]
}

The above discussion points to a number of potentially important processes affecting the local employment effects of enterprise zone policy that could be influenced by various aspects of zone programme designs and zone contexts. Mayneris and Py (2014) make a similar argument, focusing on the possible influences of initial conditions of zones in terms of density of existing firms and accessibility to workers and consumers, zone exposure to industries where firm relocation costs are lower, such as professional services, and the amount and range of tax incentives offered by the policy. Table 3 summarises some key variations across the evaluations in the nature of the zone programme designs and zone contexts evaluated. It shows that there are a number of variations in the focus of the evaluations that might be exploited for comparative analysis. These variations include whether or not the evaluated programmes made zone incentives conditional on new hiring, designated zones solely on grounds of economic distress, placed zones solely in urban locations, and operated in periods of strong or weak national labour market performance. Unfortunately, there has been relatively little deliberate comparative assessment within individual evaluations of the influences of different zone programme designs and different zone intervention contexts on local employment impacts, although some evaluations have done this. Furthermore, the data reported in the individual evaluations do not lend themselves 
to a formal meta-analysis or meta-regression on how such variations affect employment impacts because of numerous differences in the nature and definitions of the explanatory and response variables that have been used. We undertook bivariate analyses for this paper, but they showed no clear relationships between whether or not the zones generated employment benefits and variations in zone incentive tying, levels of distress, urban-rural context or national labour market performance.

On the other hand, there are some indications from specific evaluations that some of these aspects of zone programme design and context may be influencing employment impacts. One of the major criticisms of enterprise zone policy is that it may offer important windfall gains to pre-existing businesses on zones if they are able to access employment or capital subsidies intended to encourage growth without changing their behaviour (Bartik, 2001; Bartik and Eberts, 2012; Bond, Gardiner and Tyler, 2013; Neumark and Grijalva, 2013; Neumark and Simpson, 2014). For example, Neumark and Kolko (2010) highlight a situation involving Californian zones, whereby firms could retroactively claim hiring tax credits up to four years after hiring took place, implying the possibility of significant windfalls. They found that if zone managers concentrated on marketing retroactive credits to existing firms their zones created fewer jobs. Givord, Rathelot and Sillard (2013) also illustrate the windfall issue, showing that there was no impact on the economic activity of incumbent firms in French zones although they were eligible for most of the tax incentives by their simple presence in the zone. Programme designs that make subsidies conditional on new hiring might reduce this windfall effect. However, one of the few studies that compared programmes tying incentives to job creation or capital investment with those that did not found that conditioning of incentives made no difference to aggregate zone employment creation (Bondonio and Engberg, 2000).

One of the issues that been subject to significant comparative attention, at least in a minority of evaluations, is the influence of geographical context on zone employment impacts. Erikson and Friedman (1990b) found that zones were more successful if they were in 'retrievable' areas rather than severely economically distressed areas. Moore (2003) found that rural zones in California were more likely to grow than urban zones. PACEC (1995) found that employment growth was greatest in accessible suburban areas, and to a lesser extent in rural areas, and performance was weakest in the most distressed urban core areas. Lynch and Zax (2011) found that while urban zones in Colorado had no positive employment impacts, there were positive impacts in rural zones, possibly reflecting availability of an additional 
complementary subsidy there and a lower probability of capital-labour substitution. Mayer, Mayneris and Py (2017) found that policy impact was stronger in zones with larger establishment densities, suggesting that policy impact may also be influenced by agglomeration effects.

None of the evaluations included much discussion of the extent to which zone employment effects vary between periods of strong and weak overall labour market performance, although this might be expected to be a significant factor in zone performance. On the other hand, a number of other potentially important zone design and context features are highlighted by certain evaluations. Notably, the positive employment impacts of zones might be greater: in areas with more capable local development agencies (Rich and Stoker, 2010) or where an area development plan was required (Bondonio and Greenbaum, 2007); in programmes that offer a greater value or wider range of incentives (Erikson and Friedman, 1990b: Beck, 2001) and complementary job training and community development support (Beck, 2001); in zones with smaller land areas (Bondonio and Greenbaum, 2007; Erickson and Friedman, 1990b); and in zones with lower shares of manufacturing, linked to greater capital-labour substitution opportunities in manufacturing than in services (Neumark and Kolko, 2010).

Given the relatively disparate nature of the current evidence, more studies are needed that examine and report on the potential influences on zone success and which of them are important and which ways. In particular, more systematic comparative evaluations of the impact of variations in programme designs and zone contexts would be very valuable in helping inform future enterprise zone policy design.

\section{Improving data quality}

[Insert Table 4 here]

Table 4 summarises key methodological features of the reviewed evaluations. It distinguishes between a few (generally older) studies that estimated impact by surveying managers of zone-based firms and a vast majority of econometric or shift-share analyses typically comparing employment changes between treatment and control areas. It provides brief 
information on the methodologies applied. A potential weakness of the beneficiary survey methodologies is that their self-assessment impact estimates may not be reliable (Greene, 2008). Less well recognised is a potential weakness with many of the econometric studies, which, as indicated in Table 4, frequently use treatment and control data that do not fully match the policy-on and policy-off situations required for modelling.

There are three main issues. First, approximately one-half of the econometric evaluations used treatment data that did not entirely match the zone geography, generally by approximating zones with larger units that included some non-zone territory. Further, approximately one-third used control area data that included some zone territory. These imprecisions could affect the accuracy of results, particularly if zones have important spatial spillovers. Indeed, Mayneris and Py (2014) argue that poor delineation of zone boundaries together with endogeneity issues involving time-varying unobservable factors that are not picked up by difference-in-difference and propensity score matching can explain part of the conflicting results of enterprise zone evaluations to date. To help address the problems some recent studies have used precise GIS coding to attribute firms to zone and non-zone areas, whilst US federal empowerment zones boundaries were drawn up to match with census areas. Second, nearly one-half of the econometric studies used data that did not match the time periods of treatment, generally including by some non-treatment years and excluding some treatment years. Moreover, several studies examined impacts only a short time (e.g. 1 to 3 years) after zone establishment, although zones may build up jobs gradually, while very few studies took a sufficiently long view to assess whether zones have durable impacts after dedesignation. Third, several evaluations used only data for manufacturing, although zones also typically support service sector firms and there may be differences in the ways that services establishments and manufacturing establishment respond to incentives, particularly concerning capital-labour substitution. It is also worth recognising that other area-based policy interventions often operate in areas targeted by enterprise zone programmes and enterprise zone evaluations have not always sought to disentangle enterprise zone impacts from those of the other interventions.

As well as showing the estimated employment impacts of the different evaluations, Table 2 also presented a very simple characterisation of the closeness of fit of the control and treatment data used in each study. It highlights several areas in which the data used in the evaluations have not fully matched the treatment or non-treatment situations. Only around five of the evaluations were able to apply fully matching data for both the treatment and 
controls. Only 20 of the 34 studies reviewed here used control group areas that were both quite similar in economic conditions to the treatment areas and unaffected by potential spillovers. It is important to address these data issues in order to increase confidence in enterprise zone evaluation results and the policy conclusions that can be drawn from them.

\section{Conclusions}

The aggregate evaluation evidence is currently divided on whether or not enterprise zone policy is an effective and efficient tool for local employment development. While problems with the quality of data used for some evaluations may be an issue, it is likely that the major explanation for discrepancies in findings across evaluations is to do with differences in the programme designs and operating contexts of the zones they have evaluated. It is therefore a priority to increase understanding of the influence of enterprise zone programme designs and application contexts. Building the evidence required implies developing more theoreticallydriven studies that seek to identify the range of factors and channels that influence the degree of enterprise zone policy success in local employment development and how they could be affected by enterprise zone policy designs and contexts. More comparative evaluations would also help, seeking to cover multiple programme designs and contexts in the same studies. At the same time, confidence in evaluation results could be increased by efforts to improve the match between the treatment and control data and the geographies and timings of the zone interventions. A boosted enterprise zone evaluation agenda of this kind would help governments make more informed decisions about enterprise zone policy and other placebased tax incentive driven interventions for local employment development.

\section{Acknowledgements}

We would like to acknowledge the great support and encouragement provided to the authors by the late Barry Moore, Emeritus Reader in Economics at the University of Cambridge, who offered comments and suggestions on early versions of this paper and worked with us on many other projects.

\section{Disclaimer}


The paper is not based on any project of the Organisation for Economic Co-operation and Development and the views expressed are solely those of the authors and do not necessarily correspond to those of the Organisation for Economic Co-operation and Development.

\section{Declaration of conflicting interests}

The authors declared no potential conflicts of interest with respect to the research, authorship, and/or publication of this article.

\section{Funding}

This research received no specific grant from any funding agency in the public, commercial, or not-for-profit sectors.

\section{References}

Bartik, T. (1991) Who Benefits from State and Local Economic Development Policies? Upjohn Institute for Employment Research, Kalamazoo, MI.

Bartik, T. (2001) Jobs for the Poor: Can Labor Demand Policies Help? Russell Sage Foundation, New York.

Bartik, T. and Eberts, R. (2012) The Roles of Tax Incentives and Other Business Incentives in Local Economic Development, pp. 634-654 in N. Brooks, K., Donaghy and G-J. Knapp (eds) The Oxford Handbook of Urban Economics and Planning, Oxford University Press, Oxford.

Beck, F. (2001) Do state-designated enterprise zones promote economic growth? Sociological Inquiry, 71, 508-32

Billings, S. (2009) Do Enterprise Zones work? An analysis at the borders, Public Finance Review, 37, pp. 68-93

Boarnet, M.G. and Bogart, W.T. (1996) Enterprise zones and employment: Evidence from New Jersey, Journal of Urban Economics, 40, pp. 198-215. 
Bond, S., Gardiner, B. and Tyler, P. (2013) The impact of enterprise zone tax incentives on local property markets in England: who actually benefits? Journal of Property Research, 30, pp. $67-85$.

Bondonio, D. and Engberg, J. (2000) Enterprise zones and local employment: evidence from the states programs, Regional Science and Urban Economics, 30, pp. 519-549.

Bondonio, D. and Greenbaum, R. (2007) Do local tax incentives affect economic growth? What mean impacts miss in the analysis of enterprise zone policies, Regional Science and Urban Economics, 37, pp. 121-136.

Busso, M., Gregory, J. and Kline, P. (2013) Assessing the Incidence and Efficiency of a Prominent Place Based Policy, American Economic Review, 103, 897-947.

Butler, S. (1981) Enterprise Zones: Greening the Inner Cities. New York: Universe Books.

Couch, J., Atkinson, K. and Smith, L. (2005) The impact of enterprise zones on job creation in Mississippi, Contemporary Economic Policy, 23, 255-260

Dowall, D. E. (1996) An evaluation of California's Enterprise Zone programs, Economic Development Quarterly, 10, pp. 352-368.

Elvery, J. (2009) The impact of enterprise zones on resident employment: an evaluation of the enterprise zone programs of California and Florida, Economic Development Quarterly, 23.1, pp. 44-59

Erickson, R. A. and Friedman, S. W. (1990a) Enterprise zones: 1. Investment and job creation of state government programs in the United States of America, Environment and Planning C: Government and Policy, 8, pp. 251-267.

Erickson, R. A. and Friedman, S. W. (1990b) Enterprise zones: 2. A comparative analysis of zone performance and state government policies, Environment and Planning C: Government and Policy, 8, pp. 363-378.

Erickson, R. A. and Friedman, S.W. (1991) Comparative dimensions of state enterprise zone policies, in: R. E. Green (Ed.) Enterprise Zones: New Directions in Economic Development, pp. 155-176, Newbury Park, CA: Sage Publications.

Freedman, M. (2012) Targeted business incentives and local labor markets, The Journal of Human Resources, 48.2, pp. 311-344 
Fujita, M. and Thisse, J.-F. (2000) The formation of economic agglomerations: old problems and new perspectives, ch. 1, 3-73, in J.-M. Huriot and J.-F. Thisse (eds) Economics of Cities: Theoretical Perspectives, Cambridge University Press, Cambridge.

Givord, P., Rathelot, R. and Sillard, P. (2013) Place-based tax exemptions and displacement effects: An evaluation of the Zones Franches Urbaines program, Regional Science and Urban Economics, 43, pp. 151-163

Gobillon, L., Magnac, T. and Selod, H. (2010) Do Unemployed Workers Benefit from Enterprise Zones? The French Experience, ISTI working paper 645, Toulouse: Institut d’Économie Industrielle.

Gobillon, L, Selod, H. and Zenou, Y. (2007) The mechanisms of spatial mismatch, Urban Studies, 44.12, pp. 2401-2427

Greenbaum, R. and Engberg, J. (2000) An evaluation of state enterprise zone policies, Policy Studies Review, 17.2-3, pp. 29-46.

Greenbaum, R. and Engberg, J. (2004) The impact of state enterprise zones on urban manufacturing establishments, Journal of Policy Analysis and Management, 23, pp. 315-339.

Greenbaum, R. and Landers, J. (2009) Why are state policy makers still proponents of enterprise zones? What explains their action in the face of a preponderance of the research? International Regional Science Review, 32.4, pp. 466-479.

Greene, F. (2008) Assessing the Impact of Policy Interventions: The Influence of Evaluation Methodology, Environment and Planning C: Government and Policy, 27.2, 216-229.

Hall, P. (1982) Enterprise Zones: A Justification, International Journal of Urban and Regional Research, 6, pp. 417-21.

Ham, J. C., Swenson, C. Imrohoroglu, A. and Song, H. (2011) Government programs can improve local labour markts: evidence from state enterprise zones, federal empowerment zones and federal enterprise community, Journal of Public Economics, 95, 779-797

Hanson, A. (2009) Local employment, poverty and property value effects of geographically-targeted tax incentives: an instrumental variables approach, Regional Science and Urban Economics, $39.6,721-731$ 
Hanson, A. and Rohlin, S. (2011) Do location-based tax incentives attract new business establishments? Journal of Regional Science, 51, 427-449.

Hanson, A. and Rohlin, S. (2013) Do spatially targeted redevelopment programs spillover? Regional Science and Urban Economics, 43.1, 86-100.

Ihlanfeldt, K. R. and Sjoquist, D. L. (1998) The spatial mismatch hypothesis: a review of recent studies and their implications for welfare reform, Housing Policy Debate, 9, 849-92.

Kolko, J. and Neumark, D. (2010) Do some enterprise zones create jobs? Journal of Policy Analysis and Management, 29.1, pp. 5-38.

Lambert, M. E. and Coomes, P. A. (2001) An evaluation of the effectiveness of Louisville's Enterprise Zone, Economic Development Quarterly, 15, pp. 168-180.

Landers, J. (2006) Why don't enterprise zones work? Estimates of the extent that EZ benefits are capitalized into property values, Journal of Regional Analysis and Policy, 36.1, pp. 15-30

Lynch, D. And Zax, J. (2011) Incidence and Substitution in Enterprise Zone Programs: The Case of Colorado, Public Finance Review, 39, 226-255

Massey, D. (1982) Enterprise Zones: A Political Issue, International Journal of Urban and Regional Research, 6, pp. 429-34.

Mayer, T., Mayneris, F. and Py, L. (2017) The impact of Urban Enterprise Zones on establishment location decisions and labor market outcomes: evidence from France, Journal of Economic Geography, 17, 709-752

Mayneris, F. And Py, L. (2014) The Efficiency of Enterprise Zone Programs Some Conflicting Results? Banque de France, Document de Travail 474.

Moore, W. (2003) Enterprise Zones, Firm Attraction and Retention: A Study of the California Enterprise Zone Program, Public Finance and Management, 3, 376-392

Neumark, D. and Grijalva, D. (2013) The employment effects of state hiring credits during and after the Great Recession, National Bureau of Economic Research Working Paper 18928.

Neumark, D. and Kolko, J. (2010) Do enterprise zones create jobs? Evidence from California's enterprise zone program, Journal of Urban Economics, 68, pp. 1-19.

Neumark, D. and Simpson, H. (2014) Place-Based Policies, Oxford University Centre for Business Taxation Working Paper, University of Oxford. 
Oakley, D. and Tsao, H. (2006) A new way of revitalizing distressed urban communities? Assessing the impact of the federal Empowerment Zone program, Journal of Urban Affairs, 28.5, 443471.

OECD (2016) "Regional development: Policies to promote catching up", in OECD Regional Outlook 2016: Productive Regions for Inclusive Societies, OECD Publishing, Paris. DOI: http//dx.doi/10.1787/9789264260245-5-en

O’Keefe, S. (2004) Job Creation in California's Enterprise Zones: A Comparison Using a Propensity Score Matching Model, Journal of Urban Economics, 55, pp. 131-50.

PACEC (1987) An Evaluation of the Enterprise Zone Experiment. London: Her Majesty’s Stationery Office

PACEC (1995) Final Evaluation of the Enterprise Zones Experiment. London: HMSO.

Papke, L.E. (1993) What do we know about enterprise zones? in Poterba, J. M. (Ed.) Tax Policy and the Economy Volume 7, pp. 37-72, Cambridge MA: MIT Press.

Papke, L.E. (1994) Tax policy and urban development: Evidence from the Indiana enterprise zone program, Journal of Public Economics, 54, pp. 37-49.

Peters, A. and Fisher, P. (2002) State Enterprise Zone Programs: Have they worked? Kalamazoo, MI: W.E. Upjohn Institute for Employment Research.

Potter, J. and Moore, B. (2000) UK Enterprise Zones and the Attraction of Inward Investment, Urban Studies, 37, pp. 1279-1312.

Rathelot, R. and Sillard, P. (2008) Zones Franches Urbaines: quels effets sur l'emploi salarié et les créations d'établissements, Économie et Statistique, 415-416, pp. 81-96.

Rhodes, J., Tyler, P. and Brennan, A. (2007) The Single Regeneration Budget: Final Evaluation. Cambridge, University of Cambridge Department of Land Economy.

Rich, M. J. and Stoker, R. P. (2010) Rethinking Empowerment: Evidence from Local Empowerment Zone Programs, Urban Affairs Review, 45, 775-796.

Rogers, C. and Tao, J. (2004) Quasi-experimental analysis of targeted economic development programs: lessons from Florida, Economic Development Quarterly, 18, 269-285

Rubin, M. (1990) Urban enterprise zones: Do they work? Evidence from New Jersey, Public Budgeting and Finance, 10, pp. 3-17. 
Rubin, B. M. and Richards, C. M. (1992) A Transatlantic Comparison of Enterprise Zone Impacts: The British and American Experience, Economic Development Quarterly, 6, pp. 431-443.

Rubin, B. M. and Wilder, M. G. (1989) Urban Enterprise Zones: Employment Impacts and Fiscal Incentives, Journal of the American Planning Association, Autumn, pp. 418-431.

Sridhar, K. (2000) Tax Incentive Programs and Unemployment Rate, The Review of Regional Studies, 30, pp. 275-298

Wilder, M.G. and Rubin, B.M. (1996) Rhetoric versus reality: a review of studies on state enterprise zone programs, Journal of the American Planning Association, 62, pp. 473-49 
Table 1: Key design features of enterprise zone programmes in the UK, France and USA

\begin{tabular}{|c|c|c|c|c|c|}
\hline $\begin{array}{l}\text { Location and } \\
\text { period }\end{array}$ & Instruments & $\begin{array}{c}\text { Target } \\
\text { enterprises }\end{array}$ & $\begin{array}{l}\text { Life time of } \\
\text { a zone }\end{array}$ & $\begin{array}{c}\text { Number of } \\
\text { zones }\end{array}$ & Types of locations \\
\hline \multicolumn{6}{|c|}{ ACTIVE NATIONAL PROGRAMMES } \\
\hline UK 2012+ & $\begin{array}{l}100 \% \text { business rate discount up to GBP } 275000 \\
\text { Tax allowances for capital expenditure in zones } \\
\text { located in assisted regions } \\
\text { Simplified local authority planning (including } \\
\text { automatic planning permission for certain } \\
\text { development) } \\
\text { Investment in super-fast broadband } \\
\text { Business rate growth allocated to local } \\
\text { authorities for reinvestment }\end{array}$ & $\begin{array}{l}\text { New activity } \\
\text { in firms on } \\
\text { zones, } \\
\text { excluding } \\
\text { relocations }\end{array}$ & 5 years & 45 & $\begin{array}{l}\text { Urban and rural areas } \\
\text { with both distress and } \\
\text { economic potential }\end{array}$ \\
\hline France 2015+ & $\begin{array}{l}\text { Corporate tax incentives ( } 100 \% \text { in first } 5 \text { years } \\
\text { falling to } 20 \% \text { in years } 8-9) \text { of up to EUR } 50000 \\
\text { per year plus EUR } 5000 \text { for each full-time } \\
\text { hiring of a local resident }\end{array}$ & $\begin{array}{l}\text { Small firms } \\
\text { (up to } 50 \\
\text { employees) } \\
\text { employing } \\
\text { local residents } \\
\text { (one-third of } \\
\text { employees or } \\
\text { new hires) }\end{array}$ & $2015-2020$ & 100 & Distressed urban areas \\
\hline $\begin{array}{l}\text { USA Federal } \\
\text { Promise } \\
\text { Zones 2014+ }\end{array}$ & $\begin{array}{l}\text { Provision for tax incentives similar to previous } \\
\text { Empowerment Zones, if enacted by Congress } \\
\text { Preferences for certain federal grant programmes } \\
\text { Five staff to recruit and manage volunteers and } \\
\text { strengthen economic development capacity }\end{array}$ & All firms & 10 years & 22 & $\begin{array}{l}\text { Distressed urban, } \\
\text { rural and tribal } \\
\text { communities }\end{array}$ \\
\hline
\end{tabular}




\begin{tabular}{|c|c|c|c|c|c|}
\hline \multicolumn{6}{|c|}{ EXPIRED NATIONAL PROGRAMMES } \\
\hline UK 1981-2006 & $\begin{array}{l}100 \% \text { allowances for capital expenditure } \\
\text { against corporation and income tax } \\
\text { Exemption from local property taxes } \\
\text { Simplified planning including an automatic } \\
\text { right of development for specified land uses }\end{array}$ & All firms & 10 years & 32 & Distressed areas \\
\hline $\begin{array}{l}\text { France 1997- } \\
2014\end{array}$ & $\begin{array}{l}\text { Exemption for } 5 \text { years from local business } \\
\text { rates, corporate income taxes, and property } \\
\text { taxes. } \\
\text { Exemption for } 5 \text { years from employer social } \\
\text { security and health contributions on the salary } \\
\text { component below } 1.4 \text { times the minimum } \\
\text { wage, if at least one-third of the workforce is } \\
\text { resident in the surrounding urban development } \\
\text { priority area. } \\
\text { Prolonged exemption from local business tax } \\
\text { for up to } 9 \text { years depending on business size }\end{array}$ & $\begin{array}{l}\text { Firms with } \\
\text { less than } 50 \\
\text { employees }\end{array}$ & $\begin{array}{r}\text { Until expiry } \\
\text { decision }\end{array}$ & 100 & Distressed urban areas \\
\hline $\begin{array}{l}\text { USA federal } \\
\text { empowerment } \\
\text { zones 1994- } \\
2013\end{array}$ & $\begin{array}{l}\text { Employment tax credits of up to } 20 \% \text { of } \\
\text { annual wages (up to wage of USD } 15000 \text { ) } \\
\text { earned by zone residents } \\
\text { Capital gains tax exemptions, tax-exempt bond } \\
\text { financing and increased depreciation } \\
\text { allowances for business and property } \\
\text { investments } \\
\text { Social Services Block Grant funds of USD } 100 \\
\text { million per zone for business support, training } \\
\text { programmes, education, housing etc. }\end{array}$ & All firms & $\begin{array}{r}10 \text { years plus } \\
\text { extension }\end{array}$ & 40 & Distressed areas \\
\hline
\end{tabular}




\begin{tabular}{|c|c|c|c|c|c|}
\hline Alabama & $\begin{array}{l}\text { Exemptions from sales and use tax on } \\
\text { machinery and equipment and construction } \\
\text { materials } \\
\text { Tax credit for } 5 \text { years for hiring new } \\
\text { permanent employees } \\
\text { Tax credit for new investments or } \\
\text { improvements to existing facilities } \\
\text { Tax credit for training new permanent } \\
\text { employees }\end{array}$ & $\begin{array}{l}\text { Manufacturing } \\
\text { and distribution } \\
\text { firms, excluding } \\
\text { relocations }\end{array}$ & $\begin{array}{r}\text { Until expiry } \\
\text { decision }\end{array}$ & 28 & Distressed areas \\
\hline Colorado & $\begin{array}{l}\text { Tax credits for new employee hire, training } \\
\text { and health insurance } \\
\text { Tax credits for investment in equipment, } \\
\text { vehicles, building rehabilitation and research } \\
\text { and development } \\
\text { Sales and use tax credits for manufacturers } \\
\text { Tax incentives for contributions to community } \\
\text { development projects }\end{array}$ & All firms & $\begin{array}{r}\text { Until expiry } \\
\text { decision }\end{array}$ & 18 & Distressed areas \\
\hline Connecticut & $\begin{array}{l}\text { Corporate tax credit for business formation, } \\
\text { business expansion or renewal and hiring } \\
\text { Property tax credits for real estate development }\end{array}$ & $\begin{array}{l}\text { Manufacturing, } \\
\text { distribution, } \\
\text { business } \\
\text { services }\end{array}$ & $\begin{array}{r}\text { Until expiry } \\
\text { decision }\end{array}$ & 17 & $\begin{array}{l}\text { Distressed } \\
\text { communities, } \\
\text { including those with } \\
\text { defence industry } \\
\text { cutbacks }\end{array}$ \\
\hline Georgia & $\begin{array}{l}\text { Local property tax exemption } \\
\text { Abatements or reductions on occupation taxes } \\
\text { and regulatory fees }\end{array}$ & $\begin{array}{l}\text { Firms that create } \\
\text { jobs or } \\
\text { economic } \\
\text { stimulus }\end{array}$ & 10 years & 16 & Distressed areas \\
\hline Hawaii & $\begin{array}{l}\text { Exemption from General Excise Tax } \\
\text { Personal or corporate income tax and state }\end{array}$ & Non-retail firms & $\begin{array}{r}\text { Until expiry } \\
\text { decision }\end{array}$ & 22 & $\begin{array}{l}\text { Distressed census } \\
\text { tracts }\end{array}$ \\
\hline
\end{tabular}




\begin{tabular}{|c|c|c|c|c|c|}
\hline & unemployment premium credits & & & & \\
\hline Illinois & $\begin{array}{l}\text { Sales tax exemptions for building materials } \\
\text { Sales tax exemption for machinery and } \\
\text { equipment investment } \\
\text { Utility tax exemption } \\
\text { Property investment tax credit } \\
\text { Regulatory relief } \\
\text { Discretionary local incentives }\end{array}$ & $\begin{array}{l}\text { Firms that invest } \\
\text { in property or } \\
\text { invest and create } \\
\text { jobs }\end{array}$ & $\begin{array}{r}15 \text { years, } \\
\text { with possible } \\
10 \text { year } \\
\text { extension }\end{array}$ & 104 & Distressed areas \\
\hline Indiana & $\begin{array}{l}\text { Employee income tax deduction } \\
\text { Tax deductions for incremental wages paid to } \\
\text { zone residents } \\
\text { Tax credit to businesses making loans to } \\
\text { enterprise zone businesses } \\
\text { Income tax credit for individuals and } \\
\text { businesses making equity investment in zone } \\
\text { businesses } \\
\text { Property tax investment credit }\end{array}$ & All firms & $\begin{array}{r}\text { Until expiry } \\
\text { decision }\end{array}$ & 22 & $\begin{array}{l}\text { Distressed areas and } \\
\text { closed military bases }\end{array}$ \\
\hline Louisiana $^{2}$ & $\begin{array}{l}\text { Job tax credit } \\
\text { Sales and use tax rebates for machinery, } \\
\text { equipment and materials } \\
\text { Investment tax credit on capital investment }\end{array}$ & $\begin{array}{l}\text { Firms creating } \\
\text { at least } 35 \% \text { of } \\
\text { net new jobs for } \\
\text { enterprise zone } \\
\text { residents or } \\
\text { other } \\
\text { disadvantaged } \\
\text { state residents }\end{array}$ & $\begin{array}{r}\text { Until expiry } \\
\text { decision }\end{array}$ & 20 & Distressed areas \\
\hline Maryland & $\begin{array}{l}\text { Corporate income tax credits for eligible new } \\
\text { employees }\end{array}$ & All firms & 10 years & 30 & Distressed areas \\
\hline
\end{tabular}




\begin{tabular}{|c|c|c|c|c|c|}
\hline & $\begin{array}{l}\text { Local property tax credit for property } \\
\text { improvement }\end{array}$ & & & & \\
\hline Minnesota & $\begin{array}{l}\text { Sales tax exemption for construction } \\
\text { equipment and materials } \\
\text { Corporate income tax credit for additional } \\
\text { workers } \\
\text { Debt finance credit for property development } \\
\text { Property tax credit for new and expanded } \\
\text { facilities }\end{array}$ & $\begin{array}{l}\text { All firms except } \\
\text { retailing, } \\
\text { personal } \\
\text { services, } \\
\text { financial } \\
\text { institutions and } \\
\text { public utilities }\end{array}$ & Not specified & 5 & $\begin{array}{l}\text { Areas of between } 100 \\
\text { and } 400 \text { acres within } \\
\text { border cities }\end{array}$ \\
\hline Mississippi & $\begin{array}{l}\text { Full exemption on state income and franchise } \\
\text { taxes } \\
\text { Full sales and use tax exemption on equipment } \\
\text { and machinery purchases } \\
\text { Property tax exemption }\end{array}$ & $\begin{array}{l}\text { Manufacturing, } \\
\text { distribution and } \\
\text { research and } \\
\text { development } \\
\text { businesses that } \\
\text { create } 10 \text { or } \\
\text { more jobs }\end{array}$ & $\begin{array}{r}\text { Until expiry } \\
\text { decision }\end{array}$ & 18 & Distressed counties \\
\hline $\begin{array}{l}\text { New } \\
\text { Hampshire }\end{array}$ & Employee tax credit & $\begin{array}{l}\text { All firms } \\
\text { creating jobs in } \\
\text { zones }\end{array}$ & $\begin{array}{r}\text { In place until } \\
2020\end{array}$ & 189 & $\begin{array}{l}\text { Areas with vacant or } \\
\text { under-utilised } \\
\text { industrial land and } \\
\text { buildings }\end{array}$ \\
\hline New Jersey & $\begin{array}{l}\text { Reduced sales tax } \\
\text { Tax free purchases on capital equipment and } \\
\text { real estate } \\
\text { Subsidised unemployment insurance for low } \\
\text { income workers } \\
\text { Energy sales tax exemption } \\
\text { Tax credits for hire of employees and qualified } \\
\text { investments }\end{array}$ & All firms & $\begin{array}{r}\text { Until expiry } \\
\text { decision }\end{array}$ & 32 & Distressed urban areas \\
\hline
\end{tabular}




\begin{tabular}{|c|c|c|c|c|c|}
\hline New York ${ }^{3}$ & $\begin{array}{l}\text { Sales or use tax refund or credit on property, } \\
\text { utilities and certain services } \\
\text { Corporate and income tax credit for net new } \\
\text { jobs } \\
\text { Personal income tax exclusion }\end{array}$ & $\begin{array}{l}\text { Non-retail firms, } \\
\text { excluding } \\
\text { relocations, that } \\
\text { create new jobs } \\
\text { and align with } \\
\text { the mission of a } \\
\text { local higher } \\
\text { education } \\
\text { institution }\end{array}$ & 10 years & 10 & $\begin{array}{l}\text { On or near higher } \\
\text { education institution } \\
\text { campuses }\end{array}$ \\
\hline Ohio & $\begin{array}{l}\text { Local property tax incentives for property } \\
\text { investments that create jobs }\end{array}$ & $\begin{array}{l}\text { Non-retail } \\
\text { projects that } \\
\text { establish or } \\
\text { expand } \\
\text { operations in the } \\
\text { state and create } \\
\text { or maintain jobs }\end{array}$ & $\begin{array}{r}\text { Until expiry } \\
\text { decision }\end{array}$ & 400 & Distressed areas \\
\hline Oregon & $\begin{array}{l}\text { Exemption from local property taxes on plant } \\
\text { and equipment and property investments }\end{array}$ & $\begin{array}{l}\text { Non-retail } \\
\text { businesses }\end{array}$ & $\begin{array}{r}\text { In place until } \\
2025\end{array}$ & 69 & Distressed areas \\
\hline Pennsylvania & $\begin{array}{l}20 \% \text { credit against corporate income tax for } \\
\text { expenditure on real property improvements }\end{array}$ & $\begin{array}{l}\text { All firms } \\
\text { making } \\
\text { investments that } \\
\text { create } \\
\text { employment } \\
\text { opportunities for } \\
\text { low income } \\
\text { individuals }\end{array}$ & 7 years & 8 & Distressed areas \\
\hline Texas $^{2}$ & $\begin{array}{l}\text { Sales and use tax refunds on investment in } \\
\text { property, machinery and equipment based on } \\
\text { level of investment and number of jobs created }\end{array}$ & $\begin{array}{l}\text { Nominated } \\
\text { projects with at } \\
\text { least } 25 \% \text { of } \\
\text { new employees } \\
\text { from the zone or } \\
\text { disadvantaged }\end{array}$ & $\begin{array}{r}\text { Until expiry } \\
\text { decision }\end{array}$ & $\begin{array}{l}\text { Zones cover } \\
5000 \text { census } \\
\text { block } \\
\text { groups; } 23 \\
\text { entire } \\
\text { distressed }\end{array}$ & $\begin{array}{l}\text { Distressed block } \\
\text { groups or counties }\end{array}$ \\
\hline
\end{tabular}




\begin{tabular}{|c|c|c|c|c|c|}
\hline & & $\begin{array}{l}\text { populations } \\
\text { ( } 35 \% \text { if the firm } \\
\text { is located } \\
\text { outside the } \\
\text { zone) }\end{array}$ & & $\begin{array}{l}\text { counties are } \\
\text { included }\end{array}$ & \\
\hline Utah & $\begin{array}{l}\text { Employee credit - state income tax credit for } \\
\text { job creation } \\
\text { Capital investment credit - state income tax } \\
\text { credit for rehabilitating vacant buildings and } \\
\text { investment in plant, equipment and property }\end{array}$ & $\begin{array}{l}\text { All firms } \\
\text { expanding or } \\
\text { relocating to the } \\
\text { zone }\end{array}$ & 5 years & 69 & Distressed rural areas \\
\hline Virginia & $\begin{array}{l}\text { Job creation grant for creation of high wage } \\
\text { full-time jobs } \\
\text { Real Property Investment Grant } \\
\text { Local incentives }\end{array}$ & All firms & $\begin{array}{r}10 \text { years, } \\
\text { renewable } \\
\text { for } 10 \text { years }\end{array}$ & 57 & $\begin{array}{l}\text { Distressed areas with } \\
\text { offer of local } \\
\text { incentives and } \\
\text { economic potential }\end{array}$ \\
\hline Wisconsin $^{4}$ & $\begin{array}{l}\text { Job creation and retention income tax credits } \\
\text { Capital investment income tax credits for } \\
\text { property, machinery and equipment } \\
\text { Environmental remediation income tax credits }\end{array}$ & $\begin{array}{l}\text { All firms } \\
\text { excluding retail, } \\
\text { farms, financial } \\
\text { institutions, } \\
\text { hospitality, } \\
\text { media outlets, } \\
\text { primary medical } \\
\text { care }\end{array}$ & 5 years & 3 & Distressed cities \\
\hline \multicolumn{6}{|c|}{ EXPIRED US STATE PROGRAMMES ${ }^{1}$} \\
\hline $\begin{array}{l}\text { Arizona (to } \\
\text { 2011) }\end{array}$ & $\begin{array}{l}\text { Income and premium tax credit for net increases } \\
\text { in eligible employment } \\
\text { Property tax benefits for manufacturers }\end{array}$ & $\begin{array}{l}\text { All firms in } \\
\text { zones }\end{array}$ & 5 years & 19 & Various \\
\hline $\begin{array}{l}\text { Arkansas (to } \\
\text { 2003) }\end{array}$ & $\begin{array}{l}\text { Income tax credits for new hires } \\
\text { Sales and use tax on machinery and equipment }\end{array}$ & $\begin{array}{l}\text { Non-retail } \\
\text { firms }\end{array}$ & $\begin{array}{r}\text { Until expiry } \\
\text { decision }\end{array}$ & 450 & Distressed areas \\
\hline
\end{tabular}




\begin{tabular}{|c|c|c|c|c|c|}
\hline & and construction materials & & & & \\
\hline $\begin{array}{l}\text { California (to } \\
\text { 2014) }\end{array}$ & $\begin{array}{l}\text { Tax credits for hiring eligible employees } \\
\text { Sales and use tax exemptions on capital asset } \\
\text { purchases for manufacturers and research and } \\
\text { development enterprises } \\
\text { Investment tax credit }\end{array}$ & All firms & 6 years & 42 & Distressed areas \\
\hline $\begin{array}{l}\text { Florida (to } \\
\text { 2015) }\end{array}$ & $\begin{array}{l}\text { Corporate and sales tax credits for hiring } \\
\text { Sales tax credits for buildings and equipment } \\
\text { Corporate tax incentives for buildings } \\
\text { Sales tax exemption on energy } \\
\text { Tax incentives to businesses for contributions to } \\
\text { community development projects }\end{array}$ & All firms & 10 years & 65 & Distressed areas \\
\hline $\begin{array}{l}\text { Iowa (to } \\
\text { 2014) }\end{array}$ & $\begin{array}{l}\text { Local property tax exemption } \\
\text { Funding for training new employees } \\
\text { Refund of sales, service, or use taxes paid for } \\
\text { construction } \\
\text { Investment tax credit for machinery, equipment } \\
\text { and property } \\
\text { Research and development tax credit }\end{array}$ & $\begin{array}{l}\text { Non-retail } \\
\text { firms making } \\
\text { expansions or } \\
\text { relocations } \\
\text { from outside } \\
\text { the state }\end{array}$ & $\begin{array}{r}\text { Until expiry } \\
\text { decision }\end{array}$ & 61 & $\begin{array}{l}\text { Distressed counties } \\
\text { and cities }\end{array}$ \\
\hline $\begin{array}{l}\text { Kentucky (to } \\
\text { 2008) }\end{array}$ & $\begin{array}{l}\text { Machinery and equipment and building } \\
\text { materials exempt from sales and use taxes } \\
\text { Vehicles exempt from vehicle usage tax } \\
\text { Tax credit of } 10 \% \text { of wages for employees who } \\
\text { were unemployed or welfare recipients } \\
\text { Optional local tax incentives }\end{array}$ & $\begin{array}{l}\text { New } \\
\text { businesses and } \\
\text { existing } \\
\text { businesses } \\
\text { expanding } \\
\text { investment or } \\
\text { employment }\end{array}$ & 10 years & 10 & Distressed areas \\
\hline
\end{tabular}




\begin{tabular}{|c|c|c|c|c|c|}
\hline & & by $20 \%$ & & & \\
\hline $\begin{array}{l}\text { Missouri (to } \\
\text { 2013) }\end{array}$ & $\begin{array}{l}\text { Income tax and insurance tax credits for new } \\
\text { employment and investment } \\
\text { Local property tax abatement for new projects }\end{array}$ & $\begin{array}{l}\text { All firms } \\
\text { excluding } \\
\text { retail, leisure } \\
\text { and social } \\
\text { services }\end{array}$ & $\begin{array}{r}\text { Until expiry } \\
\text { decision }\end{array}$ & 115 & $\begin{array}{l}\text { Areas with distress } \\
\text { and economic } \\
\text { potential }\end{array}$ \\
\hline $\begin{array}{l}\text { New York (to } \\
\text { 2010) }\end{array}$ & $\begin{array}{l}\text { Sales tax credits and refunds } \\
\text { Property tax credit and abatements } \\
\text { Corporate tax credit } \\
\text { Wage tax credit for new hiring } \\
\text { Tax credits for new investments } \\
\text { Utility rate savings } \\
\text { Tax credit for investments in community } \\
\text { projects }\end{array}$ & All firms & $\begin{array}{r}\text { Until expiry } \\
\text { decision }\end{array}$ & 82 & $\begin{array}{l}\text { Distressed urban } \\
\text { neighbourhoods }\end{array}$ \\
\hline $\begin{array}{l}\text { Rhode Island } \\
\text { (to 2015) }\end{array}$ & $\begin{array}{l}\text { Wage tax credit of } 50 \% \text { to new full-time } \\
\text { employees and } 75 \% \text { for enterprise zone residents } \\
\text { (up to USD } 15000 \text { per employee) }\end{array}$ & $\begin{array}{l}\text { Businesses } \\
\text { that increase } \\
\text { employment } \\
\text { by } 5 \%\end{array}$ & 5 years & 10 & $\begin{array}{l}\text { Groups of up to } 5 \\
\text { census tracts with } \\
\text { distress, economic } \\
\text { potential and action } \\
\text { plans }\end{array}$ \\
\hline
\end{tabular}

Notes: ${ }^{1}$ A number of states have tiered incentives that are available across the whole state but vary in value according to the level of distress of the county or locality. They are excluded from this table and paper, which focus on programmes that limit incentives to designated zone areas within the state. States operating tiered incentive programmes include Arkansas, Maine, Missouri, Oklahoma, South Carolina and Tennessee. ${ }^{2}$ In these states, firms benefiting from incentives do not have to be located within the enterprise zone but they should hire enterprise zone residents. ${ }^{3}$ This has a somewhat different focus compared with other state enterprise zone programmes because of its emphasis on higher education institution linkages. ${ }^{4}$ This refers to the Development Opportunity Zones. Wisconsin also operates Enterprise Zone Tax Credits but they are typically designated for individual, large-scale businesses rather than localities needing regeneration. 
Table 2: Employment impact findings of seminal enterprise zone evaluation studies

\begin{tabular}{|c|c|c|c|c|c|c|c|c|}
\hline \multirow[t]{3}{*}{ Study } & \multirow[t]{3}{*}{ Location } & \multicolumn{2}{|c|}{ Key findings on employment impact } & \multicolumn{5}{|c|}{ Characterisation of quality of control and treatment group data ${ }^{1}$} \\
\hline & & \multirow{2}{*}{$\begin{array}{l}\text { Employment } \\
\text { increase or } \\
\text { unemployment } \\
\text { reduction }\end{array}$} & \multirow[t]{2}{*}{ Details } & \multicolumn{2}{|c|}{ Control group } & \multicolumn{3}{|c|}{ Treatment group } \\
\hline & & & & $\begin{array}{c}\text { Similar } \\
\text { areas }\end{array}$ & $\begin{array}{c}\text { Not } \\
\text { affected by } \\
\text { spillovers }\end{array}$ & $\begin{array}{l}\text { Exact } \\
\text { areas }\end{array}$ & $\begin{array}{c}\text { Exact } \\
\text { timings }\end{array}$ & Exact sectors \\
\hline Beck (2001) & $\begin{array}{l}\text { USA: } 51 \\
\text { zones, } \\
\text { various } \\
\text { states }\end{array}$ & $\checkmark$ & $\begin{array}{l}\text { Zones generated growth in number of } \\
\text { firms and employment. Job training } \\
\text { and community development support } \\
\text { was important for job growth. }\end{array}$ & $\checkmark$ & $x$ & $\checkmark$ & $\mathscr{r}$ & $\mathscr{L}$ \\
\hline Billings (2009) & $\begin{array}{l}\text { USA: } 16 \\
\text { Colorado } \\
\text { zones }\end{array}$ & $\checkmark$ & $\begin{array}{l}\text { Increase of between } 1.5 \text { and } 1.8 \text { new } \\
\text { jobs in new establishments and } \\
\text { between } 0.0 \text { and } 0.3 \text { new jobs in } \\
\text { existing establishments, representing } \\
\text { up to a } 3.6 \% \text { increase in employment } \\
\text { in total. }\end{array}$ & $\mathscr{L}$ & $x$ & $\mathscr{L}$ & $\mathscr{L}$ & \\
\hline $\begin{array}{l}\text { Boarnet \& Bogart } \\
\text { (1996) }\end{array}$ & $\begin{array}{l}\text { USA: } 7 \\
\text { New } \\
\text { Jersey } \\
\text { zones } \\
\end{array}$ & $x$ & No employment impact. & 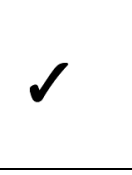 & $\mathscr{r}$ & $x$ & $\mathscr{L}$ & 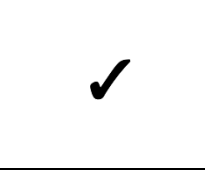 \\
\hline $\begin{array}{l}\text { Bondonio \& } \\
\text { Engberg (2000) }\end{array}$ & $\begin{array}{l}\text { USA: } 5 \\
\text { states }\end{array}$ & $x$ & $\begin{array}{l}\text { No employment impact on zone area } \\
\text { plus immediate surroundings. Impact } \\
\text { does not depend on the monetary } \\
\text { amount of the incentives or specific } \\
\text { features of programme design. }\end{array}$ & $\checkmark$ & $\checkmark$ & $x$ & $\checkmark$ & \\
\hline
\end{tabular}




\begin{tabular}{|c|c|c|c|c|c|c|c|c|}
\hline $\begin{array}{l}\text { Bondonio \& } \\
\text { Greenbaum } \\
\text { (2007) }\end{array}$ & $\begin{array}{l}\text { USA: } 10 \\
\text { states }\end{array}$ & $x$ & $\begin{array}{l}\text { No net impact on employment: } \\
\text { growth in new and existing } \\
\text { establishments offset by job losses in } \\
\text { establishments that closed or moved. } \\
\text { Restricting the geographic extent of } \\
\text { the programmes increases growth } \\
\text { from establishments new to the } \\
\text { zones. } \\
\text { Tying incentives to job creation } \\
\text { increases employment growth in } \\
\text { existing establishments. }\end{array}$ & $\mathscr{L}$ & 1 & $x$ & & $x$ \\
\hline $\begin{array}{l}\text { Busso, Gregory } \\
\text { and Kline (2013) }\end{array}$ & $\begin{array}{l}\text { USA: } 6 \\
\text { urban } \\
\text { empower- } \\
\text { ment zones }\end{array}$ & $\checkmark$ & $\begin{array}{l}\text { Employment increase in zone } \\
\text { establishments of approximately } \\
15 \% \text {. } \\
\text { By dividing the annual cost of the } \\
\text { employment tax credit by the } \\
\text { estimate of approximately } 7300 \text { new } \\
\text { jobs we can derive a cost per job of } \\
\text { approximately USD } 7500 \text { per annum } \\
\text { in current prices (approximately USD } \\
10200 \text { in } 2016 \text { prices). }\end{array}$ & $\mathscr{M}$ & $\mathscr{J}$ & $\mathscr{V}$ & $x$ & 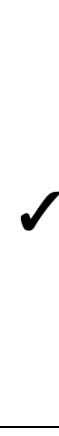 \\
\hline $\begin{array}{l}\text { Couch et al } \\
(2005)\end{array}$ & $\begin{array}{l}\text { USA: } 25 \\
\text { Mississippi } \\
\text { zones }\end{array}$ & $\checkmark$ & $\begin{array}{l}\text { Increase of } 1.5 \% \text { in the annual share } \\
\text { of new manufacturing jobs as a } \\
\text { proportion of all manufacturing jobs } \\
\text { in counties containing enterprise } \\
\text { zones. }\end{array}$ & & $\mathscr{V}$ & $x$ & $\mathscr{V}$ & $x$ \\
\hline Dowall (1996) & $\begin{array}{c}\text { USA: } 10 \\
\text { California } \\
\text { zones }\end{array}$ & $x$ & No employment impact. & & & $x$ & & 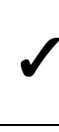 \\
\hline Elvery (2009) & $\begin{array}{l}\text { USA: } \\
\text { Florida and } \\
\text { California }\end{array}$ & $x$ & $\begin{array}{l}\text { No impact on resident employment } \\
38 \text { months after designation. }\end{array}$ & & & $x$ & & 1 \\
\hline
\end{tabular}




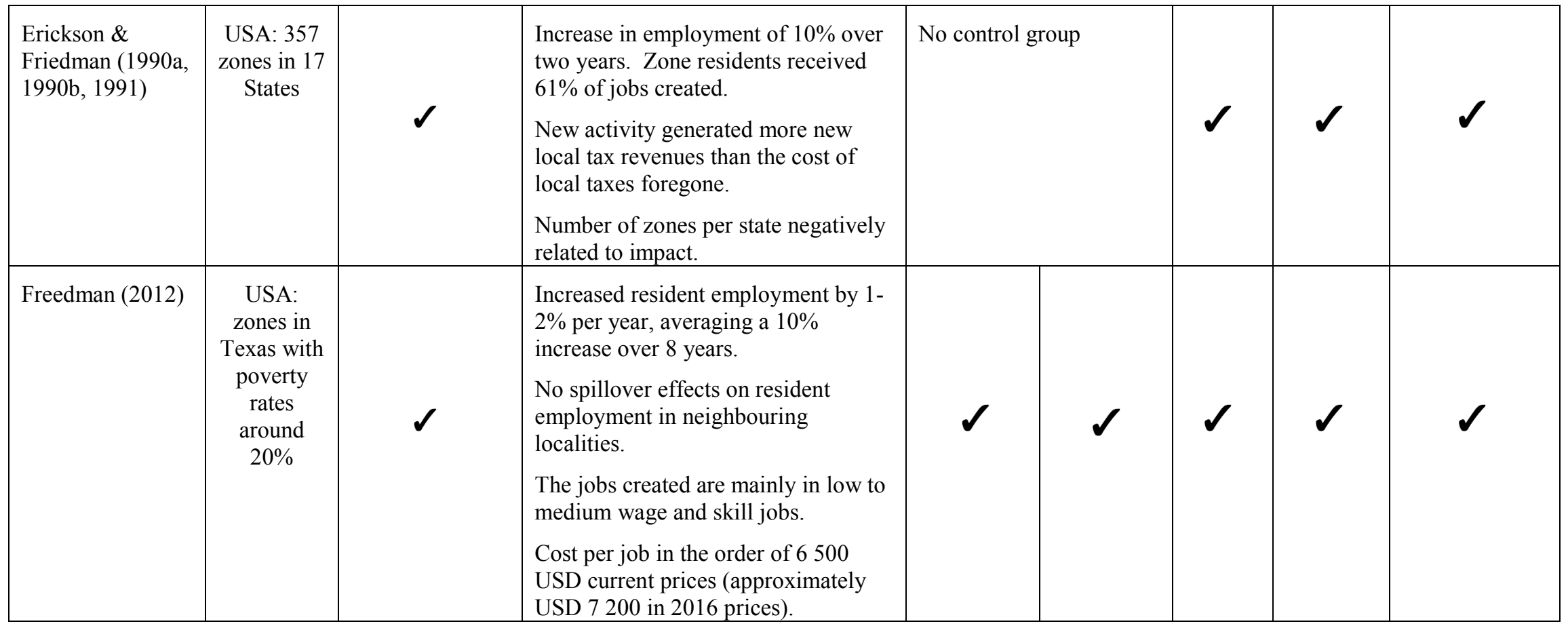




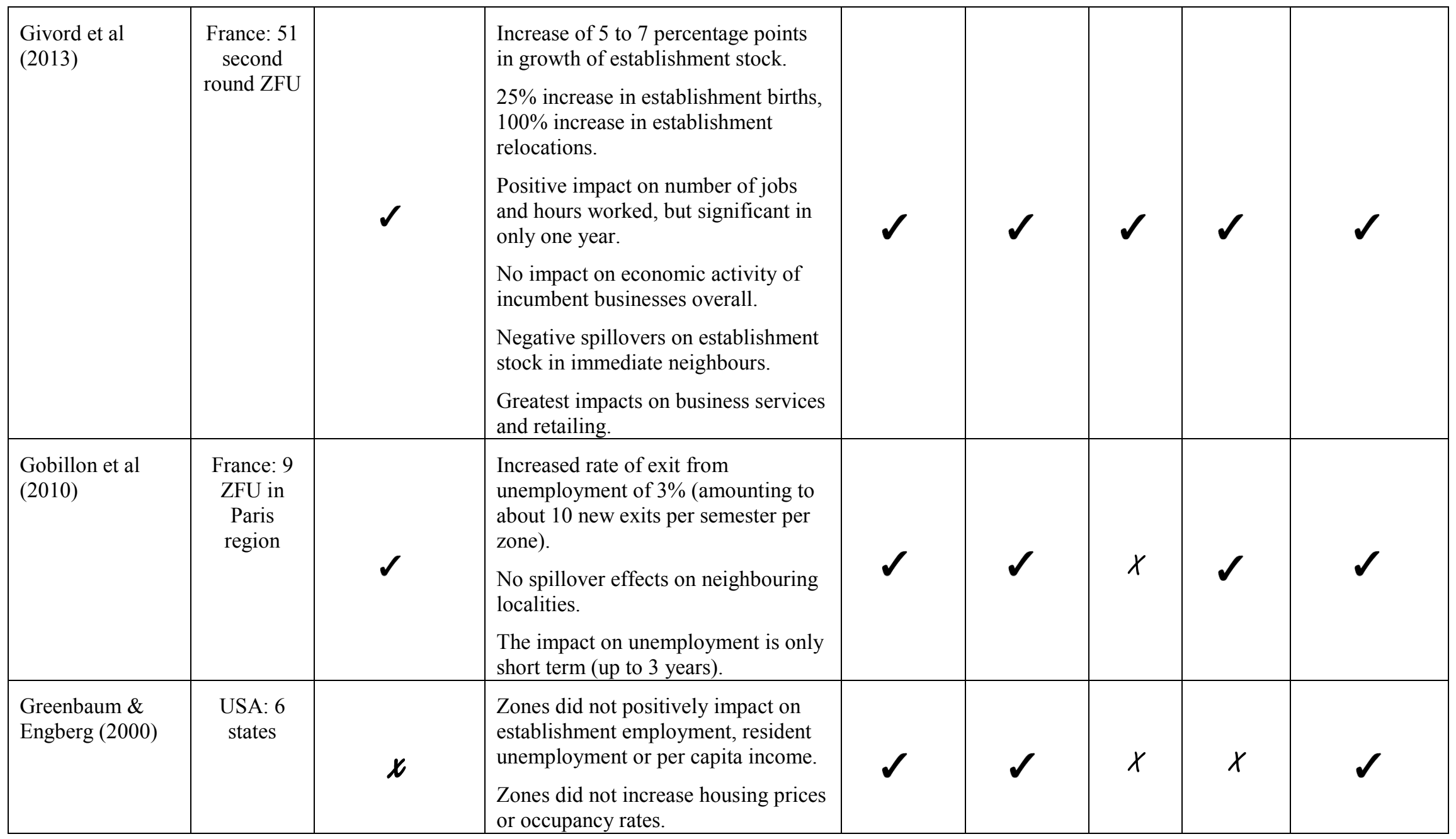




\begin{tabular}{|c|c|c|c|c|c|c|c|c|}
\hline $\begin{array}{l}\text { Greenbaum \& } \\
\text { Engberg (2004) }\end{array}$ & $\begin{array}{l}\text { USA: } 6 \\
\text { states }\end{array}$ & $x$ & $\begin{array}{l}\text { No net impact on employment: } \\
\text { growth due to births offset by } \\
\text { reduced growth in existing } \\
\text { establishments. } \\
\text { Zones did not displace activity from } \\
\text { neighbouring locations. }\end{array}$ & $\mathscr{J}$ & $\checkmark$ & $x$ & $\mathscr{V}$ & $x$ \\
\hline Ham et al (2011) & $\begin{array}{l}\text { USA: state } \\
\text { enterprise } \\
\text { zones and } \\
\text { federal } \\
\text { empower- } \\
\text { ment zones } \\
\text { in } 13 \text { states }\end{array}$ & $\checkmark$ & $\begin{array}{l}\text { Enterprise zones reduced the } \\
\text { unemployment rate by } 1.6 \text { percentage } \\
\text { points and increased employment by } \\
4 \% \text { on average. } \\
\text { Empowerment zones reduced the } \\
\text { unemployment rate by } 8.7 \text { percentage } \\
\text { points and raised employment by } \\
34 \% \text { on average. }\end{array}$ & & & $x$ & $x$ & \\
\hline Hanson (2009) & $\begin{array}{l}\text { USA: } 6 \\
\text { urban } \\
\text { empower- } \\
\text { ment zones }\end{array}$ & $x$ & $\begin{array}{l}\text { No employment impacts. } \\
\text { Subsidies appear to be absorbed by } \\
\text { increased local property values. }\end{array}$ & $\mathscr{N}$ & & $\checkmark$ & $x$ & \\
\hline $\begin{array}{l}\text { Hanson and } \\
\text { Rohlin (2011, } \\
\text { 2013) }\end{array}$ & $\begin{array}{l}\text { USA: } 6 \\
\text { urban } \\
\text { empower- } \\
\text { ment zones }\end{array}$ & $\checkmark$ & $\begin{array}{l}\text { Approximately } 20 \text { new } \\
\text { establishments and } 130 \text { jobs attracted } \\
\text { after } 5 \text { years, at a cost per job of } \\
\text { approximately USD } 2.9 \text { million in } \\
\text { current prices (approximately USD } \\
3.2 \text { million in } 2016 \text { prices). } \\
\text { Negative spillovers of approximately } \\
30 \text { establishments and } 480 \text { jobs losses } \\
\text { on neighbouring areas and } \\
\text { economically similar areas. }\end{array}$ & & & & $\mathscr{V}$ & \\
\hline $\begin{array}{l}\text { Lambert \& } \\
\text { Coomes (2001) }\end{array}$ & $\begin{array}{l}\text { USA: } 1 \\
\text { Kentucky } \\
\text { zone }\end{array}$ & $x$ & $\begin{array}{l}\text { Negative impact on employment } \\
\text { growth in the original zone area, } \\
\text { although some growth in the } \\
\text { expansion area around the airport. }\end{array}$ & & & ( & $x$ & $\mathscr{V}$ \\
\hline
\end{tabular}




\begin{tabular}{|c|c|c|c|c|c|c|c|c|}
\hline $\begin{array}{l}\text { Lynch \& Zax } \\
\text { (2011) }\end{array}$ & $\begin{array}{l}\text { USA: } \\
\text { Colorado } \\
\text { zones }\end{array}$ & Mixed & $\begin{array}{l}\text { Urban zones did not increase } \\
\text { employment per establishment. } \\
\text { Employment impacts were negative } \\
\text { for the large establishments and } \\
\text { agricultural establishments in urban } \\
\text { zones. } \\
\text { Rural zones had small positive } \\
\text { employment effects. } \\
\text { Urban and rural zones had no effect } \\
\text { on wage rates. }\end{array}$ & $\mathscr{V}$ & 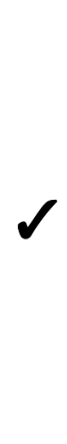 & $\mathscr{r}$ & $x$ & 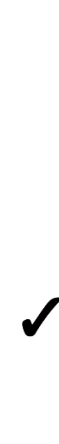 \\
\hline $\begin{array}{l}\text { Mayer, Mayneris } \\
\& \text { Py }(2003)\end{array}$ & $\begin{array}{c}\text { France: } 41 \\
\text { second } \\
\text { round } \\
\text { zones }\end{array}$ & $\checkmark$ & $\begin{array}{l}\text { Increase of } 27 \% \text { in probability that an } \\
\text { establishments will locate in the zone } \\
\text { part of their municipality. } \\
\text { Policy increases zone employment by } \\
24 \% \text { on average, with an increase of } \\
25 \% \text { in low-wage and } 11 \% \text { in non- } \\
\text { low-wage jobs. } \\
\text { All the zone impact is due to intra- } \\
\text { municipality diversion. } \\
\text { Impacts are stronger in zones with } \\
\text { higher establishment density and for } \\
\text { more mobile industries (medical } \\
\text { professions, business services). } \\
\text { No impacts on wage rates of low } \\
\text { wage workers, wage rates of non- } \\
\text { low-wage workers decline. }\end{array}$ & $\checkmark$ & $\checkmark$ & $x$ & $\checkmark$ & $\checkmark$ \\
\hline Moore (2003) & $\begin{array}{c}\text { USA: } \\
\text { California, } \\
20 \text { zones }\end{array}$ & $\checkmark$ & $\begin{array}{l}\text { Increase of } 5 \% \text { in number of firms. } \\
\text { Firm numbers explain } 80 \% \text { of } \\
\text { employment variation. } \\
\text { Growth concentrated in business } \\
\text { services, wholesaling and retailing. }\end{array}$ & $\checkmark$ & $\checkmark$ & $x$ & $\checkmark$ & $\checkmark$ \\
\hline
\end{tabular}




\begin{tabular}{|c|c|c|c|c|c|c|c|c|}
\hline $\begin{array}{l}\text { Neumark \& } \\
\text { Kolko (2010) }\end{array}$ & $\begin{array}{c}\text { USA: } \\
\text { California, } \\
42 \text { zones }\end{array}$ & $x$ & $\begin{array}{l}\text { No employment increase. } \\
\text { No shift of employment toward low- } \\
\text { wage industries. } \\
\text { Some reduction in number of } \\
\text { establishments. }\end{array}$ & $\checkmark$ & $x$ & $\checkmark$ & $\checkmark$ & $\checkmark$ \\
\hline $\begin{array}{l}\text { Oakley \& Tsao } \\
(2006)\end{array}$ & $\begin{array}{l}\text { USA: } \\
4 \text { urban } \\
\text { Empower } \\
\text { ment } \\
\text { Zones } \\
\end{array}$ & $x$ & $\begin{array}{l}\text { No impact on unemployment overall, } \\
\text { although decreases in Chicago. }\end{array}$ & $\checkmark$ & $\checkmark$ & $\checkmark$ & $x$ & $\checkmark$ \\
\hline O’Keefe (2004) & $\begin{array}{c}\text { USA: } \\
\text { California } \\
39 \text { zones }\end{array}$ & $\checkmark$ & $\begin{array}{l}\text { Increase in employment of } 3.1 \% \text { per } \\
\text { annum for first } 6 \text { years, but the effect } \\
\text { did not persist in later years. } \\
\text { Total annual cost per job in line with } \\
\text { similar programmes: USD } 2846 \text { in } \\
1996 \text { and USD } 4929 \text { in } 1995 \text { in } \\
\text { current prices (approximately USD } \\
4100 \text { and USD USD } 7300 \text { in } 2016 \\
\text { prices). }\end{array}$ & $\checkmark$ & $\checkmark$ & $x$ & $\checkmark$ & $\checkmark$ \\
\hline PACEC (1987) & $\begin{array}{l}\text { UK: } 23 \\
\text { zones }\end{array}$ & $\mathscr{V}$ & $\begin{array}{l}\text { Creation of } 13000 \text { net additional } \\
\text { jobs. } \\
\text { Cost per job of GBP } 23000 \text { in } \\
\text { current prices (approximately GBP } \\
54000 \text { in } 2016 \text { prices). }\end{array}$ & No cor & & $\checkmark$ & $\checkmark$ & $\checkmark$ \\
\hline
\end{tabular}




\begin{tabular}{|c|c|c|c|c|c|c|c|c|}
\hline $\begin{array}{l}\text { PACEC (1995) } \\
\text { Potter \& Moore } \\
(2000)\end{array}$ & $\begin{array}{c}\text { UK: } 22 \\
\text { zones }\end{array}$ & $\checkmark$ & $\begin{array}{l}58000 \text { additional jobs created (a } \\
\text { three-fold increase). } \\
\text { Annual cost per job of GBP } 1700 \text { in } \\
\text { current prices (approximately GBP } \\
2500 \text { in } 2016 \text { prices). Cost per job } \\
\text { higher on urban zones than suburban } \\
\text { and rural zones. } \\
\text { Local transfers accounted for } 35 \% \text { of } \\
\text { establishments and } 28 \% \text { of } \\
\text { employment on zones. } \\
\text { Most jobs were created in the middle } \\
\text { years of the ten-year zone designation } \\
\text { periods. }\end{array}$ & \multicolumn{2}{|c|}{ No control group } & $\checkmark$ & $\checkmark$ & $\sqrt{ }$ \\
\hline $\begin{array}{l}\text { Papke (1993, } \\
\text { 1994) }\end{array}$ & $\begin{array}{l}\text { USA: } \\
\text { Indiana } \\
\text { zones }\end{array}$ & $\checkmark$ & $\begin{array}{l}19 \% \text { reduction in the number of } \\
\text { unemployment claimants. } \\
\text { Annual cost per job created for an } \\
\text { unemployed claimant ranged across } \\
\text { zones from USD } 526 \text { to USD } 10238 \\
\text { USD in current prices (approximately } \\
\text { USD } 1000 \text { and USD } 19000 \text { in } 2016 \\
\text { prices), in line with other US job } \\
\text { subsidy schemes. }\end{array}$ & $x$ & $\checkmark$ & $x$ & $\checkmark$ & $\checkmark$ \\
\hline
\end{tabular}




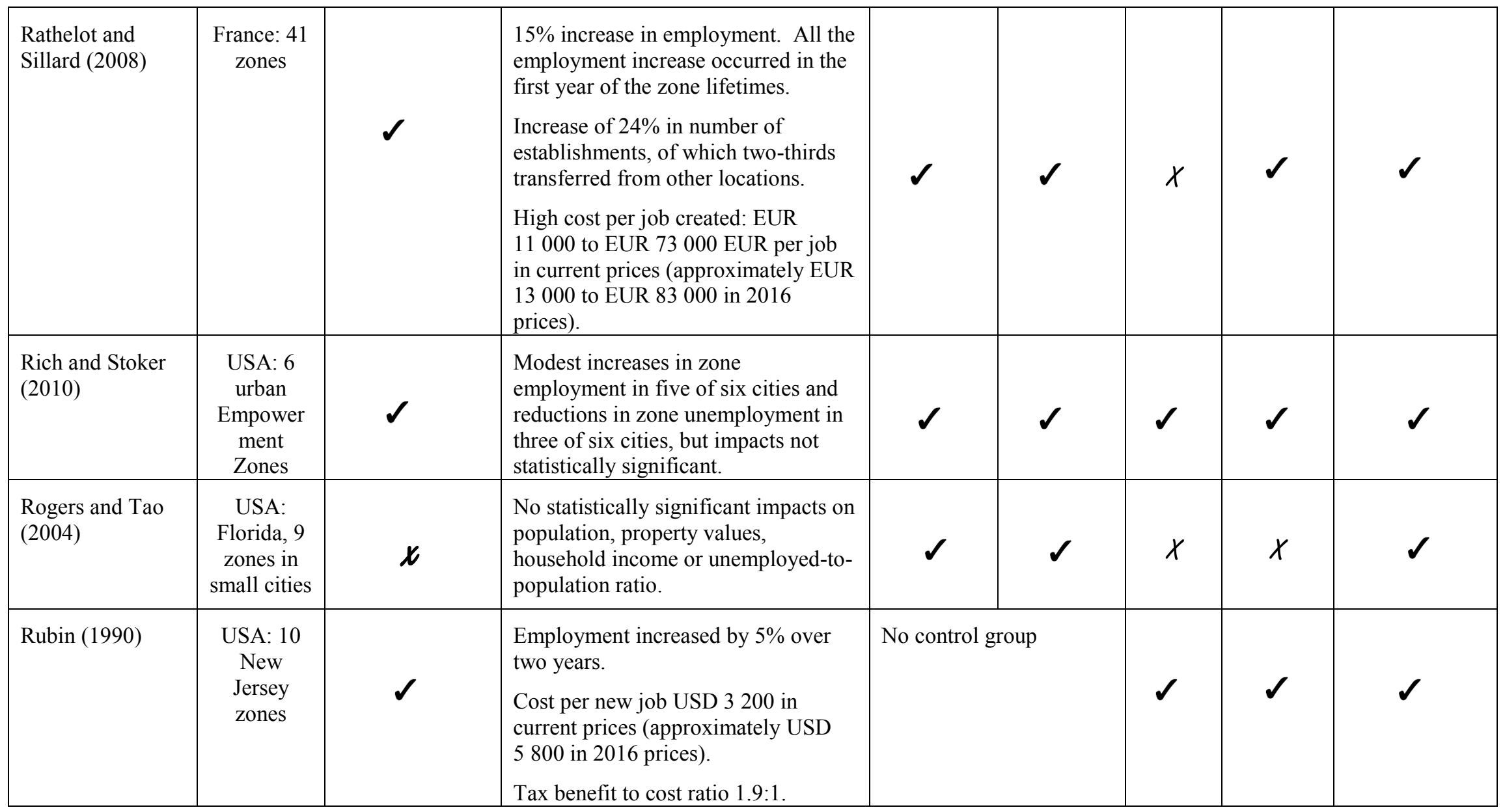


Employment increase of $36 \%$ over three years.

Average cost per new job was USD 4117 USD over 3 years or 1372 USD per year in current prices (approximately USD 7900 over 3 prices).

Job creation greater and cost per job lower in services than manufacturing.

Unemployment reduced by 2.9 percentage points in the first year of operation.

Unemployment impact appears to reduce in later years of the zones. years or USD 2600 per year in 2016

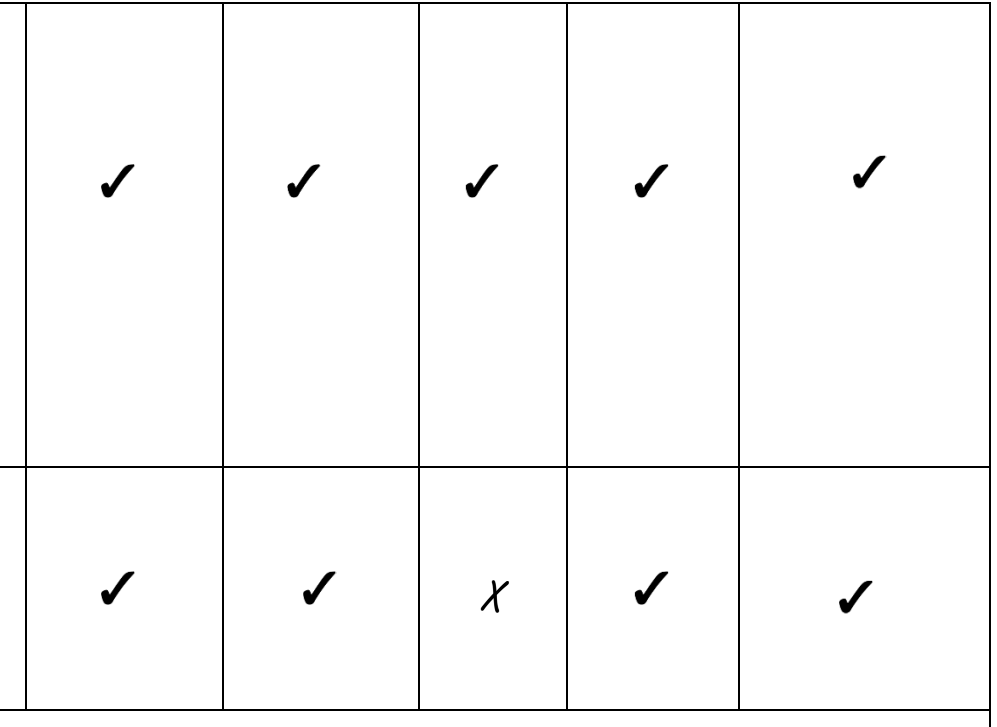

Note: ${ }^{1}$ These are broad characterisations of the approaches aimed at highlighting key issues for obtaining high quality data. It is sometimes difficult to categorise the studies but the authors have made a judgement based on the information in the relevant publication. The characterisations provided do not fully capture the extent of any mismatches (differences between minimal mismatches or major mismatches) where a mismatch is signalled. They also do not allow for the use of statistical techniques to mitigate any mismatches (e.g. difference-in-differencing). A number of studies use more than one approach, which also complicates classification. We then seek to refer to the more accurate method in the table.

Aspects of control group classification: Techniques for achieving similarity between the control group and treatment group include selecting control areas through propensity scoring, using areas that applied for but did not receive zone status, and using near neighbours. However, use of near neighbours as controls can contaminate the controls through spillovers.

Aspects of treatment group classification: The treatment group geographical areas are classed as exact if they exclude any parts of census tracts, ZIP codes etc., that are not in the zone (even if not all the zone area is included), the time periods are classed as exact if the treatment data exclude any years outside of zone lifetimes (even if excluding some years in which the zone programme was applied), and the sector match classed as exact if the data cover all the types of establishments treated (for example they are not limited to manufacturing when other sectors are affected by the treatment).

Further detail on the methods used by each study is given in Table 4 . 
Table 3 : Variations in key features of programme designs and contexts assessed by different evaluations

\begin{tabular}{|c|c|c|c|c|c|c|}
\hline \multirow[t]{2}{*}{ Study } & \multirow{2}{*}{$\begin{array}{c}\text { Key outcome variables of } \\
\text { the evaluation }\end{array}$} & \multirow{2}{*}{$\begin{array}{c}\text { Variety of } \\
\text { programme design } \\
\text { types examined }\end{array}$} & \multicolumn{2}{|c|}{ Design features of evaluated zones } & \multicolumn{2}{|c|}{ Contextual features of evaluated zones } \\
\hline & & & $\begin{array}{l}\text { Employment tying } \\
\text { of incentives }\end{array}$ & Designation criteria & $\begin{array}{l}\text { National labour market } \\
\text { trend }\end{array}$ & Geographical context \\
\hline Beck (2001) & $\begin{array}{l}\text { Workplace employment } \\
\text { Number of establishments }\end{array}$ & Multiple & Included & $\begin{array}{l}\text { Economic potential } \\
\text { included }\end{array}$ & $\begin{array}{l}\text { Undefined } \\
\text { (period varies by } \\
\text { zone) }\end{array}$ & Mixed \\
\hline Billings (2009) & $\begin{array}{l}\text { Workplace employment } \\
\text { Number of establishments }\end{array}$ & Single & Included & Distress-only & $\begin{array}{l}\text { Weak } \\
(1990-2000)\end{array}$ & Urban-only \\
\hline $\begin{array}{l}\text { Boarnet \& Bogart } \\
\text { (1996) }\end{array}$ & $\begin{array}{l}\text { Resident employment } \\
\text { Property values }\end{array}$ & Single & Included & $\begin{array}{l}\text { Economic potential } \\
\text { included }\end{array}$ & Healthy (1982-1990) & Urban-only \\
\hline $\begin{array}{l}\text { Bondonio \& } \\
\text { Engberg (2000) }\end{array}$ & Workplace employment & Multiple & Included & $\begin{array}{l}\text { Economic potential } \\
\text { included }\end{array}$ & $\begin{array}{l}\text { Weak } \\
(1984-1994)\end{array}$ & Mixed \\
\hline $\begin{array}{l}\text { Bondonio \& } \\
\text { Greenbaum (2007) }\end{array}$ & $\begin{array}{l}\text { Workplace employment } \\
\text { Capital expenditure } \\
\text { Sales } \\
\text { Wage rates }\end{array}$ & Multiple & Included & $\begin{array}{l}\text { Economic potential } \\
\text { included }\end{array}$ & $\begin{array}{l}\text { Weak } \\
(1982-1992)\end{array}$ & Urban-only \\
\hline $\begin{array}{l}\text { Busso, Gregory and } \\
\text { Kline (2013) }\end{array}$ & $\begin{array}{l}\text { Workplace employment } \\
\text { Resident employment } \\
\text { Commuter employment } \\
\text { Wages } \\
\text { Housing rents and prices }\end{array}$ & Single & Included & Distress-only & $\begin{array}{l}\text { Healthy } \\
(1994-2000)\end{array}$ & Urban-only \\
\hline
\end{tabular}




\begin{tabular}{|c|c|c|c|c|c|c|}
\hline Couch et al (2005) & Workplace employment & Single & Included & Distress-only & $\begin{array}{l}\text { Healthy } \\
(1984-1989)\end{array}$ & Mixed \\
\hline Dowall (1996) & Workplace employment & Single & Included & $\begin{array}{l}\text { Economic potential } \\
\text { included }\end{array}$ & $\begin{array}{l}\text { Healthy } \\
(1986-1990)\end{array}$ & Mixed \\
\hline Elvery (2009) & Resident employment & Multiple & Included & $\begin{array}{l}\text { Economic potential } \\
\text { included }\end{array}$ & $\begin{array}{l}\text { Weak } \\
(1987-1990)\end{array}$ & Urban only \\
\hline $\begin{array}{l}\text { Erickson \& } \\
\text { Friedman (1990a, } \\
\text { 1990b, 1991) }\end{array}$ & $\begin{array}{l}\text { Workplace employment } \\
\text { Capital investment } \\
\text { Number of establishments }\end{array}$ & Multiple & Included & $\begin{array}{l}\text { Economic potential } \\
\text { included }\end{array}$ & $\begin{array}{l}\text { Weak } \\
(1985-1987)\end{array}$ & Mixed \\
\hline Freedman (2012) & $\begin{array}{l}\text { Resident employment } \\
\text { Workplace employment } \\
\text { House values }\end{array}$ & Single & Included & Distress-only & $\begin{array}{l}\text { Weak } \\
(2002-2009)\end{array}$ & Mixed \\
\hline Givord et al (2013) & $\begin{array}{l}\text { Number of establishments } \\
\text { Workplace employment } \\
\text { Wage rates } \\
\text { Financial strength of } \\
\text { establishments }\end{array}$ & Single & No tying & Distress-only & $\begin{array}{l}\text { Weak } \\
(2004-2007)\end{array}$ & Urban-only \\
\hline $\begin{array}{l}\text { Gobillon et al } \\
\text { (2010) }\end{array}$ & $\begin{array}{l}\text { Rate of exit from } \\
\text { unemploy-ment to a job }\end{array}$ & Single & No tying & Distress-only & $\begin{array}{l}\text { Weak } \\
(1993-2003)\end{array}$ & Urban-only \\
\hline
\end{tabular}




\begin{tabular}{|c|c|c|c|c|c|c|}
\hline $\begin{array}{l}\text { Greenbaum \& } \\
\text { Engberg }(2000)\end{array}$ & $\begin{array}{l}\text { Income } \\
\text { Employment } \\
\text { Housing market }\end{array}$ & Multiple & Included & $\begin{array}{l}\text { Economic potential } \\
\text { included }\end{array}$ & $\begin{array}{l}\text { Healthy } \\
(1980-1990)\end{array}$ & Urban-only \\
\hline $\begin{array}{l}\text { Greenbaum \& } \\
\text { Engberg (2004) }\end{array}$ & $\begin{array}{l}\text { Employees in } \\
\text { manufacturing } \\
\text { establishments } \\
\text { Number of manufacturing } \\
\text { establishments } \\
\text { Turnover } \\
\text { Wage rates } \\
\text { Capital expenditure }\end{array}$ & Multiple & Included & $\begin{array}{l}\text { Economic potential } \\
\text { included }\end{array}$ & $\begin{array}{l}\text { Weak } \\
(1984-1993)\end{array}$ & Urban-only \\
\hline Ham et al (2011) & $\begin{array}{l}\text { Unemployment } \\
\text { Resident employment } \\
\text { Poverty rate } \\
\text { Fraction of households } \\
\text { with wages }\end{array}$ & Multiple & Included & $\begin{array}{l}\text { Economic potential } \\
\text { included }\end{array}$ & $\begin{array}{l}\text { Healthy } \\
(1994-2000)\end{array}$ & Mixed \\
\hline Hanson (2009) & $\begin{array}{l}\text { Resident employment } \\
\text { Resident poverty } \\
\text { Property values }\end{array}$ & Single & Included & Distress-only & $\begin{array}{l}\text { Healthy } \\
(1994-2000)\end{array}$ & Urban-only \\
\hline $\begin{array}{l}\text { Hanson and Rohlin } \\
(2011,2013)\end{array}$ & $\begin{array}{l}\text { Workplace employment } \\
\text { New establishment entry }\end{array}$ & Single & Included & Distress-only & $\begin{array}{l}\text { Healthy } \\
1994-2000\end{array}$ & Urban only \\
\hline $\begin{array}{l}\text { Lambert \& Coomes } \\
\text { (2001) }\end{array}$ & Workplace employment & Single & No tying & Distress-only & $\begin{array}{l}\text { Healthy } \\
(1980-1990)\end{array}$ & Urban only \\
\hline
\end{tabular}




\begin{tabular}{|c|c|c|c|c|c|c|}
\hline $\begin{array}{l}\text { Lynch \& Zax } \\
\text { (2011) }\end{array}$ & $\begin{array}{l}\text { Wage rates in zone } \\
\text { establishments } \\
\text { Employment in zone } \\
\text { establishments }\end{array}$ & Single & Included & $\begin{array}{l}\text { Economic potential } \\
\text { included }\end{array}$ & Weak (1990-2000) & Mixed \\
\hline $\begin{array}{l}\text { Mayer, Mayneris \& } \\
\text { Py (2003) }\end{array}$ & $\begin{array}{l}\text { Probability of an } \\
\text { establishment locating in } \\
\text { a zone } \\
\text { Workplace employment } \\
\text { Wage rates }\end{array}$ & Single & No tying & Distress-only & Weak (2004-2007) & Urban-only \\
\hline Moore (2003) & $\begin{array}{l}\text { Number of establishments } \\
\text { Workplace employment } \\
\text { Industry and size class } \\
\text { composition }\end{array}$ & Single & Included & Distress-only & Weak (1987-1991) & Mixed \\
\hline $\begin{array}{l}\text { Neumark \& Kolko } \\
(2010)\end{array}$ & $\begin{array}{l}\text { Workplace employment } \\
\text { Number of establishments } \\
\text { Industry composition of } \\
\text { employment }\end{array}$ & Single & Included & $\begin{array}{l}\text { Economic potential } \\
\text { included }\end{array}$ & $\begin{array}{l}\text { Healthy } \\
(1992-2004)\end{array}$ & Mixed \\
\hline $\begin{array}{l}\text { Oakley \& Tsao } \\
\text { (2006) }\end{array}$ & $\begin{array}{l}\text { Resident unemployment } \\
\text { Household income } \\
\text { Poverty }\end{array}$ & Single & Included & Distress-only & $\begin{array}{l}\text { Healthy } \\
(1994-2000)\end{array}$ & Urban only \\
\hline O'Keefe (2004) & $\begin{array}{l}\text { Workplace employment } \\
\text { Earnings } \\
\text { Number of establishments }\end{array}$ & Single & Included & $\begin{array}{l}\text { Economic potential } \\
\text { included }\end{array}$ & $\begin{array}{l}\text { Healthy } \\
(1992-1999)\end{array}$ & Mixed \\
\hline PACEC (1987) & $\begin{array}{l}\text { Workplace employment } \\
\text { Number of establishments }\end{array}$ & Single & No tying & Distress-only & $\begin{array}{l}\text { Weak } \\
(1981-1986)\end{array}$ & Mixed \\
\hline
\end{tabular}




\begin{tabular}{|c|c|c|c|c|c|c|}
\hline $\begin{array}{l}\text { PACEC (1995) } \\
\text { Potter \& Moore } \\
(2000)\end{array}$ & $\begin{array}{l}\text { Workplace employment } \\
\text { Number of establishments } \\
\text { Property development }\end{array}$ & Single & No tying & Distress-only & $\begin{array}{l}\text { Weak } \\
(1981-1994)\end{array}$ & Mixed \\
\hline Papke $(1993,1994)$ & $\begin{array}{l}\text { Resident unemployment } \\
\text { Capital equipment and } \\
\text { inventories }\end{array}$ & Single & No tying & $\begin{array}{l}\text { Economic potential } \\
\text { included }\end{array}$ & $\begin{array}{l}\text { Healthy } \\
(1983-1988)\end{array}$ & Urban-only \\
\hline $\begin{array}{l}\text { Rathelot and Sillard } \\
\text { (2008) }\end{array}$ & $\begin{array}{l}\text { Workplace employment } \\
\text { Number of establishments }\end{array}$ & Single & No tying & Distress-only & $\begin{array}{l}\text { Weak } \\
(2004-2006)\end{array}$ & Urban-only \\
\hline $\begin{array}{l}\text { Rich and Stoker } \\
(2010)\end{array}$ & $\begin{array}{l}\text { Resident employment } \\
\text { Unemployment } \\
\text { Poverty } \\
\text { Housing value } \\
\text { Business lending } \\
\end{array}$ & Single & Included & Distress-only & $\begin{array}{l}\text { Weak } \\
(1996-2004)\end{array}$ & Urban-only \\
\hline $\begin{array}{l}\text { Rogers and Tao } \\
\text { (2004) }\end{array}$ & $\begin{array}{l}\text { Population } \\
\text { Unemployed in } \\
\text { population } \\
\text { Median property value } \\
\text { Median household } \\
\text { income }\end{array}$ & Single & Included & $\begin{array}{l}\text { Economic potential } \\
\text { included }\end{array}$ & $\begin{array}{l}\text { Healthy } \\
(1980-1990)\end{array}$ & Mixed \\
\hline Rubin (1990) & Workplace employment & Single & Included & Distress-only & $\begin{array}{l}\text { Healthy } \\
(1983-1988)\end{array}$ & Urban-only \\
\hline
\end{tabular}




\begin{tabular}{|l|l|l|l|l|l|l|}
\hline $\begin{array}{l}\text { Rubin \& Wilder } \\
\text { (1989) }\end{array}$ & Workplace employment & Single & No tying & $\begin{array}{l}\text { Economic potential } \\
\text { included }\end{array}$ & $\begin{array}{l}\text { Healthy } \\
(1983-1986)\end{array}$ \\
\hline Sridhar (2000) & Unemployment & Single & No tying & $\begin{array}{l}\text { Economic potential } \\
\text { included }\end{array}$ & $\begin{array}{l}\text { Healthy } \\
(1982-1990)\end{array}$ \\
\hline
\end{tabular}

Note: The evaluation is reported as including employment-tying if any incentives in the evaluated programmes were conditional on new recruitment or another positive employment outcome. Evaluations were characterised as focusing on distress if areas were principally selected for designation because of high unemployment and poverty. The national labour market tendency is characterised as healthy if the national unemployment rate reduced by at least two percentage points over the period of the study; otherwise it is characterised as weak. Evaluations are characterised as urban-only if all the evaluated zones were in urban areas and mixed if they included both urban and rural zones. 
Table 4: Summary of key methodological and data features of enterprise zone evaluation studies

\begin{tabular}{|c|c|c|c|c|c|}
\hline \multirow[t]{2}{*}{ Study } & \multicolumn{2}{|c|}{ Basic approach } & \multirow[b]{2}{*}{$\begin{array}{l}\text { Treatment data } \\
\text { characteristics }\end{array}$} & \multirow[b]{2}{*}{ Control group specification } & \multirow[b]{2}{*}{ Description of method } \\
\hline & $\begin{array}{l}\text { Beneficiary } \\
\text { firm survey }\end{array}$ & $\begin{array}{l}\text { Employment } \\
\text { trends } \\
\text { comparison } \\
\end{array}$ & & & \\
\hline Beck (2001) & & $\mathscr{V}$ & $\begin{array}{l}\text { Precise zone area. } \\
\text { Precise time period } \\
\text { from zone } \\
\text { designation to } \\
\text { evaluation. }\end{array}$ & $\begin{array}{l}\text { Neighbouring areas: counties } \\
\text { surrounding zones. }\end{array}$ & $\begin{array}{l}\text { Employment growth comparison of the } \\
\text { zones and surrounding counties over } \\
\text { the lifetime of the zone. }\end{array}$ \\
\hline $\begin{array}{l}\text { Billings } \\
(2009)\end{array}$ & & $\checkmark$ & $\begin{array}{l}\text { Precise zone area. } \\
\text { Annual. }\end{array}$ & $\begin{array}{l}\text { Neighbouring areas: establishments } \\
\text { just inside the zone border matched } \\
\text { with establishments in areas just } \\
\text { outside the border with similar } \\
\text { numbers of establishments or } \\
\text { establishment death rates. }\end{array}$ & $\begin{array}{l}\text { Difference-in-differences in } \\
\text { employment growth comparing } \\
\text { establishments inside and outside of the } \\
\text { zones accounting for region and } \\
\text { establishment characteristics and time. }\end{array}$ \\
\hline $\begin{array}{l}\text { Boarnet \& } \\
\text { Bogart } \\
(1996)\end{array}$ & & $\mathscr{N}$ & $\begin{array}{l}\text { Combine zone and } \\
\text { surroundings } \\
\text { (municipalities). } \\
\text { Annual. }\end{array}$ & $\begin{array}{l}\text { Distant-and-similar areas: } \\
\text { municipalities containing zones } \\
\text { matched with qualifying or applicant } \\
\text { municipalities without zones. }\end{array}$ & $\begin{array}{l}\text { Panel regression of municipal } \\
\text { employment change against zone status } \\
\text { with instrumental variables to account } \\
\text { for endogeneity of zone designation. }\end{array}$ \\
\hline $\begin{array}{l}\text { Bondonio } \\
\text { and Engberg } \\
(2000)\end{array}$ & & 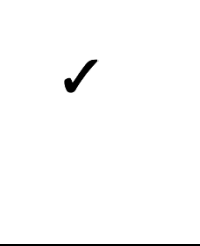 & $\begin{array}{l}\text { Combine zone and } \\
\text { surroundings (zip } \\
\text { codes). Annual. }\end{array}$ & $\begin{array}{l}\text { Distant-and-similar areas: zip codes } \\
\text { containing zones or parts of zones } \\
\text { compared with zip codes with no zone } \\
\text { coverage with matched zone } \\
\text { designation propensity scores. }\end{array}$ & $\begin{array}{l}\text { Panel regression of employment } \\
\text { change against zone status controlling } \\
\text { for area-specific fixed effects and } \\
\text { growth rates, plus a panel regression } \\
\text { controlling for designation probability } \\
\text { for each area. }\end{array}$ \\
\hline
\end{tabular}




\begin{tabular}{|c|c|c|c|c|c|}
\hline $\begin{array}{l}\text { Bondonio \& } \\
\text { Greenbaum } \\
\text { (2007) }\end{array}$ & & $\checkmark$ & $\begin{array}{l}\text { Combine zone and } \\
\text { surroundings (zip } \\
\text { codes). 5-year } \\
\text { interval. } \\
\text { Manufacturing only. }\end{array}$ & $\begin{array}{l}\text { Distant-and-similar areas: non-zone } \\
\text { areas with matched zone designation } \\
\text { propensity scores. }\end{array}$ & $\begin{array}{l}\text { Panel data for manufacturing } \\
\text { establishments with at least five } \\
\text { employees for eleven states. Fixed } \\
\text { effects model regressing employment } \\
\text { growth rate against zone status and } \\
\text { aspects of policy design. Propensity } \\
\text { scores included in the growth rate } \\
\text { regression. }\end{array}$ \\
\hline $\begin{array}{l}\text { Busso, } \\
\text { Gregory and } \\
\text { Kline } \\
(2013)\end{array}$ & & $\checkmark$ & $\begin{array}{l}\text { Precise zone area. 10- } \\
\text { year interval. }\end{array}$ & $\begin{array}{l}\text { Distant-and-similar areas: rejected and } \\
\text { future zone census tracts in other cities. }\end{array}$ & $\begin{array}{l}\text { Difference-in-differences of outcomes } \\
\text { between treated and untreated tracts } \\
\text { weighted by propensity scores on zone } \\
\text { designation. }\end{array}$ \\
\hline $\begin{array}{l}\text { Couch et al } \\
(2005)\end{array}$ & & $\Omega$ & $\begin{array}{l}\text { Combine zone and } \\
\text { surroundings } \\
\text { (counties). Annual. } \\
\text { Manufacturing only. }\end{array}$ & $\begin{array}{l}\text { Both neighbouring and distant areas: } \\
\text { all counties in state without a zone }\end{array}$ & $\begin{array}{l}\text { Regression analysis on impact of zone } \\
\text { designation on share of new jobs in all } \\
\text { manufacturing jobs. }\end{array}$ \\
\hline $\begin{array}{l}\text { Dowall } \\
(1996)\end{array}$ & & $\checkmark$ & $\begin{array}{l}\text { Combine zone and } \\
\text { surroundings (zip } \\
\text { codes). Annual. }\end{array}$ & $\begin{array}{l}\text { Both neighbouring and distant areas, } \\
\text { covering the entire county. }\end{array}$ & $\begin{array}{l}\text { Shift-share analysis identifying change } \\
\text { in zone employment attributable to } \\
\text { county-wide growth, industry mix and } \\
\text { residual zone impact. }\end{array}$ \\
\hline $\begin{array}{l}\text { Elvery } \\
(2009)\end{array}$ & & $\checkmark$ & $\begin{array}{l}\text { Combine zone and } \\
\text { surroundings (census } \\
\text { tracts). Annual. }\end{array}$ & $\begin{array}{l}\text { Distant-and-similar areas: zone and } \\
\text { non-zone areas with matched zone } \\
\text { designation propensity scores, } \\
\text { excluding non-zone areas bordering on } \\
\text { a zone. }\end{array}$ & $\begin{array}{l}\text { The neighbourhood component of } \\
\text { employment growth is compared } \\
\text { between zones and matched non-zone } \\
\text { areas, after controlling for pre-zone } \\
\text { characteristics of residents. }\end{array}$ \\
\hline $\begin{array}{l}\text { Erickson \& } \\
\text { Friedman } \\
(1990 \mathrm{a}, \\
\text { 1990b, } \\
\text { 1991) }\end{array}$ & $\checkmark$ & & $\begin{array}{l}\text { Precise zone area. } \\
\text { Annual. }\end{array}$ & No control group. & $\begin{array}{l}\text { Postal survey of local zone co- } \\
\text { ordinators identifying employment } \\
\text { associated with new establishments, } \\
\text { expanded establishments and closures } \\
\text { prevented. }\end{array}$ \\
\hline
\end{tabular}




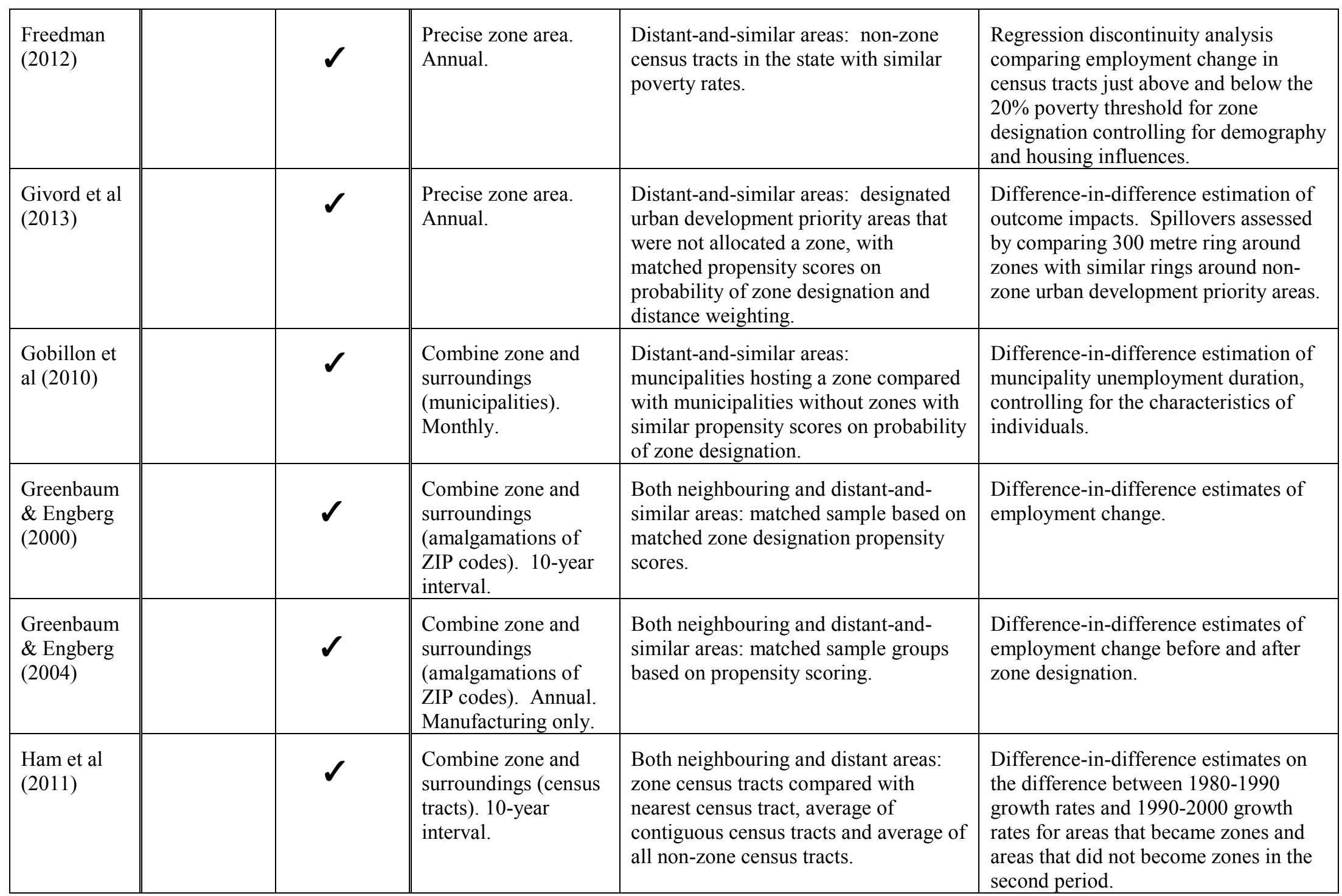




\begin{tabular}{|c|c|c|c|c|}
\hline $\begin{array}{l}\text { Hanson } \\
(2009)\end{array}$ & $\checkmark$ & $\begin{array}{l}\text { Precise zone area. 10- } \\
\text { year interval. }\end{array}$ & $\begin{array}{l}\text { Both neighbouring and distant-and- } \\
\text { similar areas: rejected zone applicant } \\
\text { areas. }\end{array}$ & $\begin{array}{l}\text { Differencing of resident employment } \\
\text { change } 1990-2000 \text { for zone tracts and } \\
\text { surrounding cities in designated zones } \\
\text { and rejected zones, with an } \\
\text { instrumental variable to allow for } \\
\text { selection effects. }\end{array}$ \\
\hline $\begin{array}{l}\text { Hanson and } \\
\text { Rohlin } \\
\text { (2011, } \\
\text { 2013) }\end{array}$ & $\checkmark$ & $\begin{array}{l}\text { Precise zone area. } \\
\text { Trend data spans } \\
\text { three years. }\end{array}$ & $\begin{array}{l}\text { Both neighbouring and distant-and- } \\
\text { similar areas: rejected zone applicants }\end{array}$ & $\begin{array}{l}\text { Differencing of establishment } \\
\text { employment change } 1994-2000 \text { for } \\
\text { zone tracts and surrounding cities in } \\
\text { designated zones and rejected zones, } \\
\text { with an instrumental variable to allow } \\
\text { for selection effects. }\end{array}$ \\
\hline $\begin{array}{l}\text { Lambert \& } \\
\text { Coomes } \\
(2001)\end{array}$ & $\checkmark$ & $\begin{array}{l}\text { Precise zone area. } 10- \\
\text { year interval. }\end{array}$ & $\begin{array}{l}\text { Both neighbouring and distant areas: } \\
\text { zones compared with the county as a } \\
\text { whole and two non-zone subcounty } \\
\text { areas, one of which was contiguous. }\end{array}$ & $\begin{array}{l}\text { Shift-share analysis controlling for } \\
\text { industrial structure. }\end{array}$ \\
\hline $\begin{array}{l}\text { Lynch \& } \\
\text { Zax (2011) }\end{array}$ & $\checkmark$ & $\begin{array}{l}\text { Precise zone area. 10- } \\
\text { year interval. } \\
\text { Excludes } \\
\text { establishments } \\
\text { moving on or off } \\
\text { zones. }\end{array}$ & $\begin{array}{l}\text { Distant-and similar areas: Matched } \\
\text { non-zone establishments throughout } \\
\text { the state. }\end{array}$ & $\begin{array}{l}\text { Heckit and Tobit regressions on } \\
\text { employment and wage rates in zone } \\
\text { and non-zone establishments in } 2000 \\
\text { (when the new policy equilibrium had } \\
\text { time to come into effect), controlling } \\
\text { for establishment sector, } 1990 \text { size, } \\
1990 \text { wage, independence, and county } \\
\text { characteristics. }\end{array}$ \\
\hline
\end{tabular}




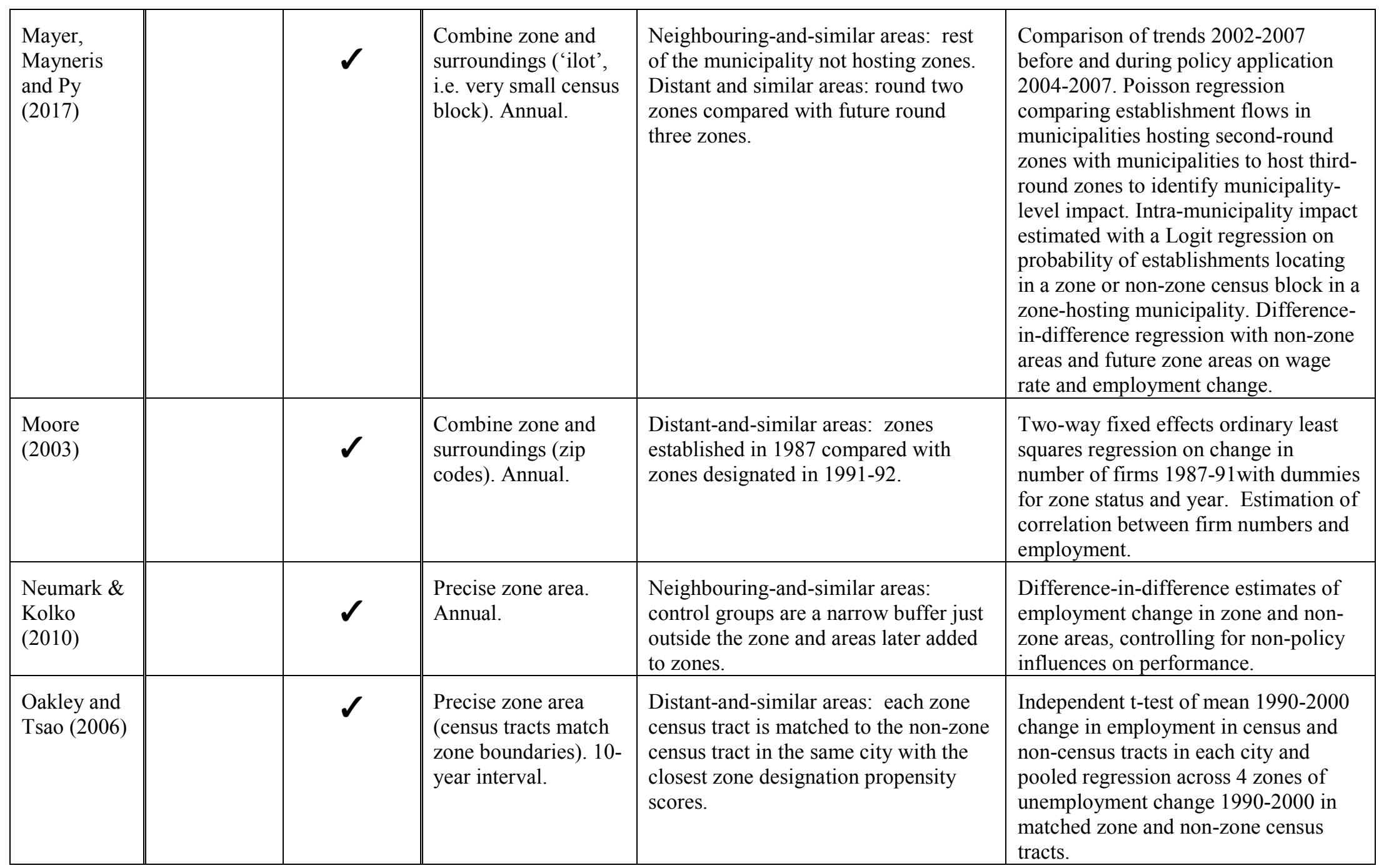




\begin{tabular}{|c|c|c|c|c|c|}
\hline $\begin{array}{l}\text { O'Keefe } \\
\text { (2004) }\end{array}$ & & $\checkmark$ & $\begin{array}{l}\text { Combine zone and } \\
\text { surroundings (census } \\
\text { tracts). Annual. }\end{array}$ & $\begin{array}{l}\text { Distant-and-similar areas: zones are } \\
\text { matched to the non-zone areas with the } \\
\text { closest zone designation propensity } \\
\text { scores in the same county. }\end{array}$ & $\begin{array}{l}\text { Regression of employment change in } \\
\text { zone and matched non-zone areas, } \\
\text { controlling for area fixed effects and } \\
\text { with separate variables for zones with } \\
\text { greater and less than } 7 \text { years life. }\end{array}$ \\
\hline $\begin{array}{l}\text { PACEC } \\
(1987)\end{array}$ & $\checkmark$ & & $\begin{array}{l}\text { Precise zone area. } \\
\text { One-off survey. Mid- } \\
\text { term in zone lifetime. }\end{array}$ & No control group. & $\begin{array}{l}\text { 'On-zone' firm managers estimated } \\
\text { how zone policy had affected their size } \\
\text { and location. }\end{array}$ \\
\hline $\begin{array}{l}\text { PACEC } \\
(1995) \\
\text { Potter and } \\
\text { Moore } \\
(2000)\end{array}$ & $\checkmark$ & & $\begin{array}{l}\text { Precise zone area. } \\
\text { One-off survey. End } \\
\text { of zone lifetime. }\end{array}$ & No control group. & $\begin{array}{l}\text { 'On-zone' firm managers estimated } \\
\text { how zone policy had affected their size, } \\
\text { location and start-up decisions. } \\
\text { Displacement, linkage, multiplier } \\
\text { analysis used to estimate total local } \\
\text { economy effects. }\end{array}$ \\
\hline $\begin{array}{l}\text { Papke } \\
(1993, \\
1994)\end{array}$ & & $\checkmark$ & $\begin{array}{l}\text { Combine zone and } \\
\text { surroundings } \\
\text { (unemployment } \\
\text { claims offices } \\
\text { covering a city) } \\
\text { Annual. } \\
\end{array}$ & $\begin{array}{l}\text { Distant areas: zones compared with } \\
\text { randomly selected urban non-zones of } \\
\text { comparable size within the state. }\end{array}$ & $\begin{array}{l}\text { Difference-in-differences of } \\
\text { employment change controlling for } \\
\text { fixed and random effects. }\end{array}$ \\
\hline $\begin{array}{l}\text { Rathelot and } \\
\text { Sillard } \\
(2008)\end{array}$ & & $\checkmark$ & $\begin{array}{l}\text { Combine zone and } \\
\text { surroundings (census } \\
\text { tracts). Annual. }\end{array}$ & $\begin{array}{l}\text { Distant-and-similar areas: zones } \\
\text { compared with non-zone areas in } \\
\text { surrounding urban policy target zone } \\
\text { with matched zone designation } \\
\text { propensity scores. }\end{array}$ & $\begin{array}{l}\text { Differences-in-differences comparison } \\
\text { of employment growth. }\end{array}$ \\
\hline $\begin{array}{l}\text { Rich and } \\
\text { Stoker } \\
(2010)\end{array}$ & & $\checkmark$ & $\begin{array}{l}\text { Precise zone area. } \\
\text { Data for three years. }\end{array}$ & $\begin{array}{l}\text { Both neighbouring and distant-and- } \\
\text { similar areas: matched pairs of zones } \\
\text { and eligible tracts within the city with } \\
\text { matched zone designation propensity } \\
\text { scores. }\end{array}$ & $\begin{array}{l}\text { Treatment effect calculated as sum of } \\
\text { change in zone area minus change in } \\
\text { control area divided by number of } \\
\text { treatment areas. Bootstrapping yielded } \\
\text { a sample distribution for statistical } \\
\text { significance estimation. }\end{array}$ \\
\hline
\end{tabular}




\begin{tabular}{|c|c|c|c|c|c|}
\hline $\begin{array}{l}\text { Rogers and } \\
\text { Tao (2004) }\end{array}$ & & $\checkmark$ & $\begin{array}{l}\text { Combine zone and } \\
\text { surroundings (census } \\
\text { tracts). } 10 \text {-year } \\
\text { interval. }\end{array}$ & $\begin{array}{l}\text { Distant-and-similar areas: small cities } \\
\text { that qualified for zone status but did } \\
\text { not apply. }\end{array}$ & $\begin{array}{l}\text { Compared log mean change in } \\
\text { response variable for treatment and } \\
\text { control group and regression including } \\
\text { political and economic controls. Does } \\
\text { not allow for self-selection bias in } \\
\text { decision to apply. }\end{array}$ \\
\hline $\begin{array}{l}\text { Rubin } \\
(1990)\end{array}$ & $\checkmark$ & & $\begin{array}{l}\text { Precise zone area. } \\
\text { One-off survey. }\end{array}$ & No control group. & $\begin{array}{l}\text { Zone firms estimated how policy had } \\
\text { affected their location and expansion } \\
\text { decisions. Input-output analysis used to } \\
\text { estimate linkage and multiplier effects. }\end{array}$ \\
\hline $\begin{array}{l}\text { Rubin \& } \\
\text { Wilder } \\
\text { (1989) }\end{array}$ & & $\checkmark$ & $\begin{array}{l}\text { Precise zone area. } \\
\text { Annual. }\end{array}$ & $\begin{array}{l}\text { Both neighbouring and distant areas: } \\
\text { metropolitan area as a whole. }\end{array}$ & $\begin{array}{l}\text { Shift-share analysis identifying change } \\
\text { in zone employment attributable to } \\
\text { metropolitan area growth, industry mix } \\
\text { and residual zone impact. }\end{array}$ \\
\hline $\begin{array}{l}\text { Sridhar } \\
(2000)\end{array}$ & & $\checkmark$ & $\begin{array}{l}\text { Combine zone and } \\
\text { surroundings (census } \\
\text { tracts). Data for one } \\
\text { year only. }\end{array}$ & $\begin{array}{l}\text { Both neighbouring and distant areas: } \\
\text { zone tracts compared with non-zone } \\
\text { tracts in the state. }\end{array}$ & $\begin{array}{l}\text { Two-stage least squares regression of } \\
\text { unemployment change against } \\
\text { predicted zone status controlling for } \\
\text { socio-economic factors. }\end{array}$ \\
\hline
\end{tabular}


Figure 1: A theoretical framework for investigating local employment and growth effects of enterprise zones

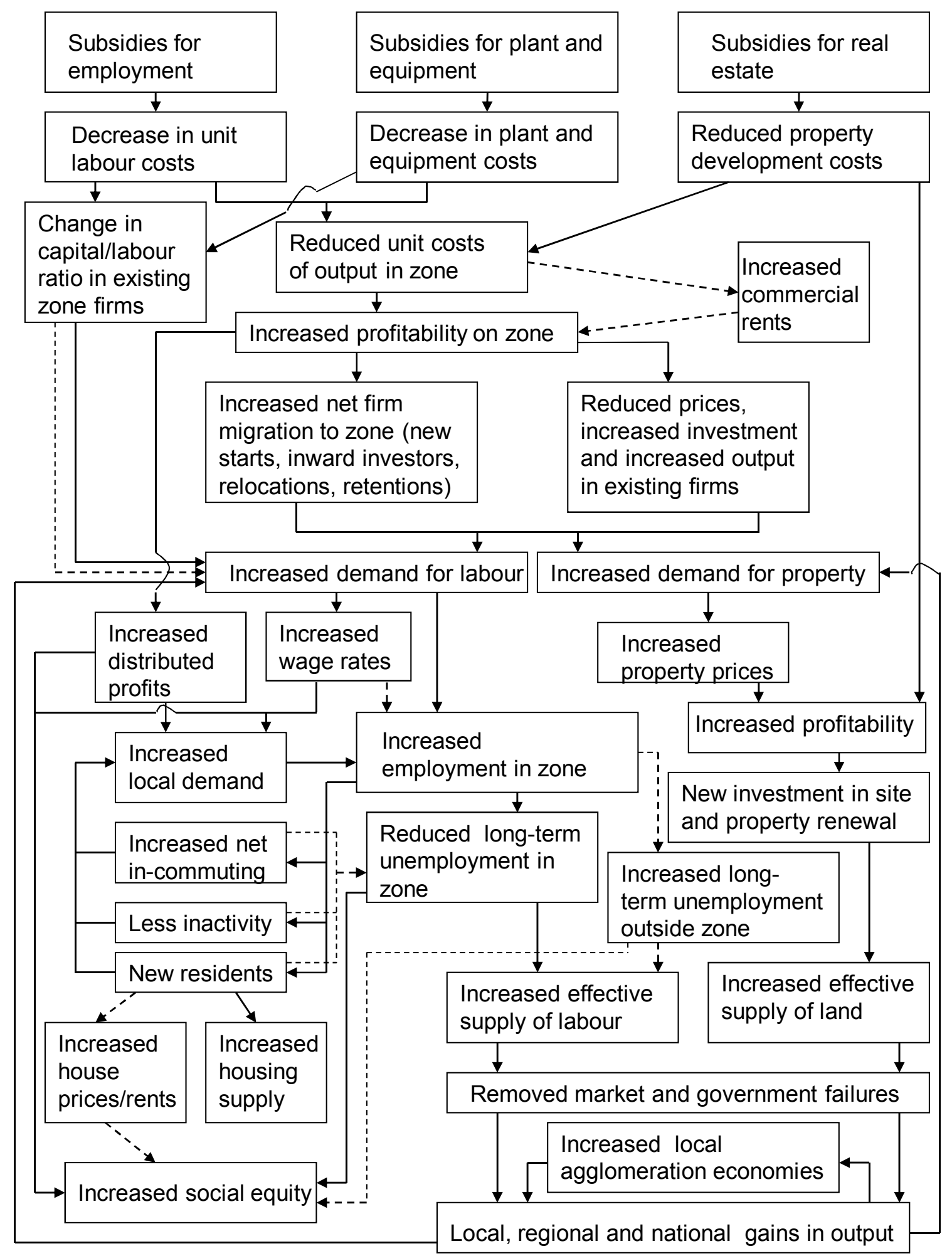

Note: A dashed line indicates a possible negative impact channel. 